\title{
FORMAL AND INFORMAL PATRONAGE AMONG JEWS IN THE ISLAMIC EAST: EVIDENCE FROM THE CAIRO GENIZA
}

\author{
MECENAZGO FORMAL E INFORMAL ENTRE JUDÍOS \\ EN EL MUNDO ISLÁMICO ORIENTAL: ALGUNOS \\ EJEMPLOS DE LA GENIZA DE EL CAIRO
}

\author{
MARINA RuSTOW \\ Emory University
}

This paper investigates the political culture of the Islamic East under Fatimid and Buwayhid rule (tenth-twelfth centuries) via relationships between patrons, clients, protégés, and partners. The main body of evidence I utilize are letters and petitions from the Cairo Geniza that employ the same specialized vocabulary of patron-client relationships one finds in Arabic histories of the period: idioms referring to the exchange of benefit, reciprocal service, protection, oversight, patronage, and loyalty. The Geniza letters, written without regard for posterity, suggest that these idioms were used well beyond the courts and were understood and deployed by men and women, the literate and illiterate, the important and the inconsequential. Yet the use of certain terms in Judaeo-Arabic also differs from their use in Arabic: some reflect devaluation over time, while others hardened into formulaic phrases. These differences suggest that some forms of patronage did not thrive beyond the hothouse of the court; viewed from another perspective, they also suggest that even outside courtly literature, one can retrieve fossils of older forms of patronage in the terms used to describe relationships between leaders and their followers as well as among people more nearly equal in station. A society's use of social metaphors reveals something of what its members value, what they choose to retain and perpetuate from the past, how they function in moments of crisis, and how successfully their rulers have managed to convince them of the
Este artículo aborda la cultura política del Oriente islámico bajo gobierno fatimí y buwayhí (siglos X al XII) a partir de las relaciones entre mecenas, clientes, protegidos y socios. Se centra en el análisis de cartas y peticiones de la Geniza de El Cairo que usan el mismo vocabulario especializado que las fuentes árabes históricas de la época a la hora de describir las relaciones entre patrón y cliente: expresiones que hacen referencia al intercambio de beneficios, servicios recíprocos, protección, supervisión, patronazgo y lealtad. Las cartas de la Geniza, escritas sin ningún afán de pasar a la historia, sugieren que esas expresiones circulaban fuera del contexto cortesano y que hombres y mujeres, letrados $\mathrm{y}$ analfabetos, gentes de alto y bajo rango, las entendían y las usaban. Aun así, el uso de ciertos términos en judeo-árabe y en árabe difiere: algunos términos parecen haber experimentado cierta erosión, mientras que otros parecen haberse convertido en meras fórmulas. Esas diferencias indican que algunas formas de patronazgo no prosperaron más allá del entorno puramente cortesano; por otro lado, también indican que se pueden encontrar antiguas formas de patronazgo fosilizadas en términos usados para describir las relaciones entre los líderes y sus seguidores, o entre gente de categorías sociales más próximas, incluso fuera de la literatura cortesana. El uso que una sociedad hace de las metáforas sociales pone de manifiesto lo que sus miembros valoran, los aspectos del pasado que deciden conservar y perpetuar, el 
legitimacy of the social and political order. Conversely, the vocabulary of patronage was a social technique that allowed Jews to conduct business, engage in politics and communal regulation, and to amass and retain followers in a variety of spheres, including that of the rabbinic academies who proffered the construction of Judaism that became hegemonic over the course of the Middle Ages.

Key words: Medieval Jews; Judeo-Arabic; Cairo Geniza; Patronage; Etiquette. modo en que funcionan en los momentos de crisis y la capacidad que sus gobernantes tienen de convencerles o no de la legitimidad del orden político-social. A su vez, el vocabulario del patronazgo fue una técnica social que permitió que los judíos llevaran sus negocios, tomaran parte activa en la normativa política y comunitaria, y acumularan y retuvieran seguidores en varias esferas distintas, incluida la de las academias rabínicas, una esfera en la que se gestó el judaísmo medieval hegemónico.

Palabras clave: Judíos en la Edad Media; judeo-árabe; Geniza de El Cairo; patronazgo; etiqueta.

Scholarship on the political culture of the Islamic East under Abbasid-Buwayhid rule has noted the pervasiveness of patron-client relationships, seemingly informal vertical alliances that substituted for formal institutional structures binding courtiers to rulers and armies to the regimes they served. ${ }^{1}$ But most of the evidence of courtly life - chronicles, biographical dictionaries, belles lettres, treatises on administration, and mirrors for princes - comes to us via literary sources composed at court or under courtly patronage, a fact that raises the question of whether those relationships were principally an artefact of the writings in which they appeared. At court, one required

1 Others have made similar observations about relationships between teachers and their students and among long-distance traders during the same period over a greater swath of territory. Goitein, S.D., "Formal Friendship in the Medieval Near East," Proceedings of the American Philosophical Society, 115 (1971), 484-89; Mottahedeh, R., "Admistration in Buyid Qazwin," in D.S. Richards (ed.), Islamic Civilisation 950-1150, Oxford, 1973, 33-45; Udovitch, A.L., "Formalism and Informalism in the Social and Economic Institutions of the Medieval Islamic World," in A. Banani and S. Vryonis (eds.), Individualism and Conformity in Classical Islam, Wiesbaden, 1977, 61-81; Mottahedeh, R., Loyalty and Leadership in an Early Islamic Society, Princeton, 1980; Udovitch, A.L., "Merchants and Amirs: Government and Trade in Eleventh-century Egypt," Asian and African Studies, 22 (1988), 53-72; Berkey, J.P., The Transmission of Knowledge in Medieval Cairo: A Social History of Islamic Education, Princeton, 1992; and Ephrat, D., A Learned Society in a Period of Transition: The Sunni 'Ulamā' of Eleventh Century Baghdad, Albany, 2000. This trend has not gone unchallenged: see, e.g., Petry, C.F., "Educational Institutions as Depicted in the Biographical Literature of Mamluk Cairo: The Debate over Prestige and Venue," Medieval Prosopography, 23 (2002), 101-23; Stewart, D.J., "The Doctorate of Islamic Law in Mamluk Egypt and Syria," in J. Lowry, D.J. Stewart and S. Toorawa (eds.), Law and Education in Medieval Islam: Studies in Memory of George Makdisi, Cambridge, 2004, 45-90. 
patronage in order to survive. Did similar networks of ties of dependency between the powerful and their protégés characterize life outside the courts as well?

Patronage, clienthood, and detailed and reciprocal sets of obligations in social and political life did indeed extend beyond the courts and into the circles of men and women of humbler rank. The purpose of this article is to demonstrate this on the basis of personal letters preserved in the Cairo Geniza that employ precisely the specialized idioms of patron-client relationships that one finds in the courtly literature. The similarities between the courtly and documentary records are striking and must be explained; the differences, too, are instructive. The similarities suggest either that Jews maintained contacts with the court and read courtly literature, or that this shared lexicon of patronage and loyalty functioned in a wider range of contexts than has been previously supposed. There were, in fact, direct contacts between Jews and the caliphal courts of Baghdad and Cairo in the tenth, eleventh, and twelfth centuries, in the form of courtiers, bureaucrats, and Jewish communal leaders trained in the canons of Arabic diplomatic (insh $\left.\bar{a}^{\prime}\right)$. In the present analysis, however, I lean toward the second explanation: the parallels between courtly literature and everyday letters demonstrate how deeply the modes and manners that we ascribe to courtly etiquette permeated other realms of relationships whose stability rested on the binding power of loyalty. As to the differences, the documentary sources suggest that in an era when the pages of courtly literature were replete with metaphors of patronage, in wider usage some of those metaphors had been transformed into mere fossils, ossified remnants of the era of self-conscious patronage preserved in the literary sources.

The texts I have examined are all private letters exchanged between individuals. Unlike the Greek and Latin letters of antiquity, they were never intended for public consumption or recitation, and were not transmitted or copied by anyone, save the occasional student learning to write or young scribe practicing his craft. They were strictly private pieces, discarded and rediscovered a millennium later, and for that reason they offer a glimpse of how seriously people took matters of patronage and loyalty when, unlike the court chroniclers, they were not describing them for posterity or with some lofty literary purpose in mind. 
Those letters suggest that even when formal legal or institutional arrangements governed the obligations between patrons and their protégés, both parties to the relationship reminded one another of those obligations in affective terms. Both Roy Mottahedeh and A.L. Udovitch have noted this, contending that allies were more likely to describe their duties and commitments toward one another as arising from loyalty and gratitude for benefaction than in terms of the legal requirements that bound them to one another; both have described a particular mixture of formalism and informalism that governed social and political relationships in the medieval Islamic East. ${ }^{2}$ Mottahedeh, while focusing on courtiers, hypothesized that sustained patronage was "an important means of creating new ties on all levels of life; and, undoubtedly," he adds, "if we had more information on the lowest levels of life, we would see it at work in the relations of landlords to peasants and of grocers to sweepers." ${ }^{3}$ What he proffered as a mere suspicion can, in fact, be demonstrated: the vocabulary of patronage functioned among the lower classes, and it functioned in contexts that were, at best, very loosely centralized, juridically undefined, and for the most part entirely lacking in coercive mechanisms. At court, one recited one's part in the patron-client drama out of fear of the frequently dire consequences, including but not limited to death, that might follow on missed cues and political blunders; outside that fraught and enclosed world, one played one's role in consideration of what Mottahedeh calls "the calculus of benefaction ( $n$ i ' $m a$ )," a social code, defined obliquely if at all, that regulated exchanges of benefit and according to which one gave or received patronage. ${ }^{4}$

2 Mottahedeh, Loyalty and Leadership, 84; Udovitch, "Formalism and Informalism;" but cf. now Lieberman, Ph., "A Partnership Culture: Jewish Economic and Social Life Seen through the Legal Documents of the Cairo Geniza" (PhD dissertation, Princeton, 2007), who argues against Udovitch that partnerships between traders were, in fact, regulated by legal instruments and institutions and did not rest principally upon informal or affective bonds. For a complementary argument on behalf of the blended uses of both formal and informal strategies among traders, see Goldberg, J.L., "The Geographies of Trade and Traders in the Eastern Mediterranean 1000-1150: A Geniza Study," PhD dissertation, Columbia, 2005, especially chapter 2 .

3 Mottahedeh, Loyalty and Leadership, 90.

4 Ibidem, e.g., 82; alternately, "calculus of mutual liability," 74.

Al-Qanțara (AQ) XXIX 2, julio-diciembre 2008, pp. 341-382 ISSN 0211-3589 


\section{Patronage Formal and Informal}

What, precisely, does the English word patronage mean, and is it of any use in discussing Arabic sources?

Defined in the most general way possible, patronage entails using one's political power, financial means, or other types of influence to advance one's interests. The type of patronage with which most of the essays in this volume are concerned led to the production of works of art, literature, architecture, science, and philosophy via a relationship in which the patron had a particular role to play, sometimes not just as a supporter of culture but as a producer of it. ${ }^{5}$ Patronage was a means by which rulers and their courts advanced their claims as the bestowers of material and cultural benefits on the populace; it was both one of the unspoken obligations of kingship and a means by which rulers achieved legitimacy — or the veneer of it - in the eyes of their subjects. Even though, as Patricia Crone has recently noted, none of the mirrors for princes states that rulers are obligated to mete out fiscal support for cultural production, the benefits that caliphs, sultans, viziers, and amirs accrued from doing so were tangible enough to convince them to fund such endeavours, establish pious foundations ( $a w q \bar{a} f$ or $a h b \bar{a} s$ ) for them, and devote line-items to them in the fiscal budget. 6

This type of patronage, however, is a subtype of the broader range of courtly patronage, in which interests of all kinds were advanced through the power and influence of those in the courtly hierarchy. Those interests included narrowly political ones in which cultural production played no part. Yet this sort of patronage, too, played a role in legitimating regimes and rulers. An extreme instance of this, as Crone has maintained, was the growing dependence of the Abbasids on clientage, and in particular on the ranks of slave-soldiers and other servile protectors of the regime; the dynasty used them, she argues, as a desperate and last-ditch effort to augment its power in the absence of convincing political meaning. ${ }^{7}$ This kind of patronage too, then, could serve the purposes of political legitimation.

\footnotetext{
${ }^{5}$ See especially Gruendler, B., Medieval Arabic Praise Poetry: Ibn al-Rumi and the Patron's Redemption, London and New York, 2003, 9-10.

${ }^{6}$ Crone, P., God's Rule: Government and Islam: Six Centuries of Medieval Islamic Political Thought, New York, 2004, 312-13.

7 Idem, Slaves on Horses: The Evolution of the Islamic Polity, Cambridge, 1980.
}

Al-Qanțara (AQ) XXIX 2, julio-diciembre 2008, pp. 341-382 ISSN 0211-3589 
The type of patronage with which Crone is concerned came to be theorized by the jurists of the eighth century as wala' - literally, "proximity," but more technically, patronage or clientage, a special type of legal relationship that, in its early stages, allowed non-Arabs to join the ranks of the Muslim umma despite their foreign origin. ${ }^{8}$ By means of the formal patron-client bond, non-Arabian converts to Islam assumed, through a form of fictive kinship, the benefits of alliance with one of the Arab Muslim tribes - in theory, with the individual who had converted them; in practice, with the entire community of believers - and in exchange, these converts were bound to provide their patrons with services and, when they died, material bequests. The institution of wala 'also extended to manumitted slaves, who became the clients of their former owners. ${ }^{9}$

During the early centuries of Islamic rule the institution of wala transformed almost beyond recognition, mainly as a result of the Abbasid revolution, which extended the privileges formerly reserved for Arabs to non-Arab Muslims. After the Abbasid rise to power, wala ' was no longer a means of integrating non-Arabs into the ranks of Islamic society, since they were already integrated; it came instead to refer more strictly to the relationship between manumitters and their former slaves. Those slaves' descendants, however, were no longer considered clients (mawāli $)$ : this type of patronage was not transferable by legacy, and the mawäli never came to constitute an "ethnic" or otherwise hereditary group. That freed the wala' arrangement to serve other purposes. And indeed, the Abbasid rulers relied heavily on their own clients in the formal sense of those whom they had personally manumitted and, perhaps, in the sense of those whom they had "made" through favours and benefactions. Clients of the caliphal

${ }^{8}$ Crone, P., Roman, Provincial and Islamic Law: The Origins of the Islamic Patronate, Cambridge, 1987, 91.

9 Ibidem (for an introduction to walä' see chap. 3, and for its history, chap. 7); see also idem in $E l^{2}$, s.v. "Mawlä." For historical studies on the mawāli as a class, see the essays collected in Bernards, M. and Nawas, J. (eds.), Patronate and Patronage in Early Classical Islam, Leiden, 2005; for Sunnī legal theory on walä' and a partial revision of Crone's argument that the origins of walä' lie in the koine of provincial law under Roman rule, see Mitter, U., "Origin and Development of the Islamic Patronate," in ibidem, 70-134; and for a radically skeptical reconsideration of the extent of wala' as practiced and its primacy as a form of conversion to Islam, see Bulliet, R.W., "Conversion-based Patronage and Onomastic Evidence in Early Islam," in ibidem, 246-62, an argument partially anticipated in Crone, Slaves on Horses, 237 footnote 358.

Al-Qanțara (AQ) XXIX 2, julio-diciembre 2008, pp. 341-382 ISSN 0211-3589 
household came, in the late second and early third/ninth century, to form a distinct group at court and to hold governorates and other high ranking positions throughout the realm, as the high incidence of governors and other local headsmen styled mawlä amìr al-mu'minin (client of the commander of the faithful) attests. ${ }^{10}$ Still others formed armies through a modified form of wala ${ }^{\prime}$ - the origins of the slave-soldier institution that dominated the Near Eastern military beginning in the second/ninth century and continued to do so up until the nineteenth. ${ }^{11}$

Here, the conundrum of whether and when to read an Arabic word as a technical term has created some confusion. The term used to designate both the patron and the client in this institution - mawla - had admitted of broader and informal uses at the top end, but was over time loosened on the bottom end too, and used to refer not just to the parties in the legal relationship of wala', but to new kinds of patrons and clients alike; hence it is not always clear in which sense a source is calling someone a mawlä. Over time, the term mawla came to be used for patrons, benefactors, lords, and masters of all types, as the specificity of the legal institution of walä' gave way to a generalized structure of hierarchy and dependency in which the court cultivated clients because its own stability and safety depended on it. By the eleventh century, the term mawla was used broadly, and it is abundantly reflected in chancery petitions and private requests alike in which the grandee of whom the request was made is styled a mawla merely by virtue of being petitioned for something. An aphorism of Abù 1-'Alā' al-Ma'arrī (973-1058) acknowledges this situation obliquely: "If a person refrains from injuring me," he writes, suggesting that personal loyalty outweighs religious conviction, "/ Then he will have bounty (suqyā) and protection $\left(r u^{\prime} y \bar{a}\right)$ his entire life. // If he wants, let him learn the book of Moses, / Or if he likes, let him become a client (yudmiru walä'a) of Sha' yā" - the latter a reference to a Jewish trading clan that was one of the most illustrious mercantile

${ }^{10}$ Crone, Slaves on Horses, 67, and the examples cited there, 75, 78, 258 footnote 610, 259 footnote 616, and Appendix V, n. ${ }^{\circ}$ 24, 29, 32, 36, 37, 38, 39, 43, 45, 47, and 48. There are likely to be numerous Egyptian mawäli of this kind waiting to be found in papyri; see, e.g., Austrian National Library, P. Vind. AP 762, recto, edited in Rustow, M., "A Record of Obligation (dhikr haqq) Dated 242 AH (856-857)," in W. Diem, G. Khan and P.M. Sijpesteijn (eds.), Arabische Urkunden, Berlin, forthcoming.

11 Crone, Slaves on Horses, 74-81; idem, "Mawlā," EI .

Al-Qanțara (AQ) XXIX 2, julio-diciembre 2008, pp. 341-382 ISSN 0211-3589 
dynasties of the late eleventh century. If in the poet's view even Jews and traders could practice clientage, then surely the ties of wala' ' had come to mean something very different from the legal institution reflected in the work of the jurists. ${ }^{12}$

One of the chief features of patronage in the later, looser sense was the reciprocal nature of the obligations it entailed. The amphibolous nature of the term mawlā, which, at least in its origins, could denote both patrons and clients, reflects the fact that the institution, by its nature, ascribed benefits and responsibilities to those on both sides of the tie. Even after the term came to be used for lords rather than their dependents, it was still widely understood that the benefits and responsibilities exchanged on both sides created mutually obligatory bonds; and that those bonds were susceptible of reinforcement through verbal admonition, a subject about which I will have more to say below.

Personal ties of clientage, then, were still pervasive and important in the tenth, eleventh, and twelfth centuries; but they took on meanings different from those they had borne in the two classical eras of wala', the Umayyad period with its basically tribal structure of clientage ties, and the Abbasid period with its use of clientage as a means of developing a vast network of retainers, one so vast that it ultimately took over the state itself in the form of the Buwayhids. But while most agree on the importance of clientage, not all agree on how to value the phenomenon. While Crone finds this new form of patronage that originated in the Abbasid crisis of political meaning in the late second/eighth century to have been ultimately self-annihilating, Mottahedeh views patronage in a very different mode, considering the social meanings of the informal side of clientage in relations between the courts and their armies and secretaries as the regime foundered. For Crone, the Abbasid dependence on clientage contained the seeds of the regime's decadence and, with the Buwayhid takeover of Iraq and Iran in the fourth/tenth century, turned the house of Abbas into fainéants (a term calqued from the Merovingian rois fainéants,

12 Idhā l-insānu kaffa l-sharra 'anñ̄ / fa-suqyā fì l-hayāti lahu wa-ru'yā // Wa-yadrusu in arāda kitāba Mūsā / wa-yudmiru in ahabba walà'a Sha 'yā. Nicholson, R.A., Studies in Islamic Poetry, Cambridge, 1969, n. ${ }^{\circ}$ 309, 284 (Arabic); cf. his English translation, 196. Goitein, S.D., A Mediterranean Society: The Jewish Communities of the Arab World as Portrayed in the Documents of the Cairo Geniza, Berkeley, 1967-93, 3,10, identifies this Sha'yā as a member of the Jewish mercantile family. 
"idle kings," and indeed Crone compares the consolidation of the Buwayhids and Seljuks with that of the Carolingians after the Merovingian decline). ${ }^{13}$ For Mottahedeh, by contrast, patronage served as the main form of social coherence and political continuity after the demise of Abbasid rule — as a kind of informal glue holding society together in the absence of central or formal political institutions. While Crone focuses on the formal institution of clientage; its inadequacy and, finally, exhaustion as a means of politics; and its ultimate responsibility for the mamlūk institution, Mottahedeh focuses on informal patronage among courtiers and ghilmān as holding the political system in place. Ghilmān - slave boys whose dependence on their patrons, frequently the caliph himself, began in childhood and remained total even in adulthood - became the incarnation of Abbasid fainéance; yet in Mottahedeh's hands, the lesson of the ghilmann is that the affective ties of men who rose together or made their own clients could and did substitute for strong political institutions. ${ }^{14}$ These two arguments -in books published in the same year- agree on the symptoms of Abbasid decadence, and even on their causes. But while Crone's is a sustained exercise in negative judgment meant to explain the failure of the Abbasid polity and the birth of a characteristically Islamic political institution, the slave-soldier regime, Mottahedeh understands patronage in an anthropological vein as a sign of resilience: as he puts it, "from the point of view of the social historian, the weakness of government threw society back on its own resources." 15

Questions of judgment aside, Crone's analysis stresses the formal aspects of the arrangement while Mottahedeh focuses on the informal ones. This difference reflects the fact that the word patronage refers to at least three things in the context of medieval Islamicate courts and societies: granting political and economic benefits in exchange for cultural production; the formal legal institution of wala'; and more broadly, the bonds of benefaction and dependence between all kinds of patrons and clients. But all three types revolve around a common ethos. It is that ethos that this article intends to describe, as evidenced

13 Crone, Slaves on Horses, 82, 265 footnote 649.

14 Mottahedeh, Loyalty and Leadership, 84-89.

15 Ibidem, 39.

Al-Qanțara (AQ) XXIX 2, julio-diciembre 2008, pp. 341-382 ISSN 0211-3589 
by tenth-, eleventh- and twelfth-century sources of courtly and non-courtly provenance.

\section{Idioms of patronage}

One characteristic of ties of patronage as they emerge in the sources is that they came to be expressed in particular kinds of language; language, in turn, took on particular characteristics when it expressed social values. While the vocabulary of patron-client relationships dated back to the Umayyads and took on particular meaning under the Abbasids, by the Buyid period it had begun to assume new importance and even unprecedented meanings precisely because it evoked long-dead institutions. The court and the bureaucracy held themselves together partly out of a certain adherence to past forms and idioms. This formalistic recycling of the linguistic structures of a political life long past imbued idioms of patronage with double meaning: they both referred to relationships in the present and invoked an era when the Abbasids still ran their own court and the caliph was more than a mere idler. One can even sense the gesture in the work of Buwayhid historians such as al-Miskawayh (ca. 932-1030), whose chronicle conjures up a dense and ultimately highly idealized picture of court etiquette under the Abbasids, as if he was at pains to show continuities with a past long past. He did this not in order to protect the regime, of which he was openly critical in a way he could not have been a century earlier, or to shore up its legitimacy, but because (like Mottahedeh himself) he was possessed of a fascination with the forms and gestures of social life.

Indeed, Mottahedeh's anatomy of patronage is based principally on Buyid chronicles by the likes of al-Miskawayh and Abū Hayyān al-Tawhīdī (d. 1023), and one suspects that these two medieval authors' abiding interest in ethics and gossip respectively coloured what they remembered and chose to represent of life at court. ${ }^{16}$ Mottahedeh's great contribution to understanding their work and that of their contemporaries was to elucidate the relationship between lan-

16 Ibidem; see especially 82-95, where he argues that the affective ties of istina ' (patronage, fostering someone's career) were more important than the legal ties of wal $\bar{a}^{\prime}$ in material from this period.

Al-Qanțara (AQ) XXIX 2, julio-diciembre 2008, pp. 341-382 ISSN 0211-3589 
guage and the social. Indeed, the chief interpretive problem the historian faces in reading Arabic sources, as Sauvaget and Cahen once put it, is recognizing the "precise technical nuance in the meaning of a word," distinguishing technical from non-technical terms, or recognizing when words bear worlds of meaning and when they do not. ${ }^{17}$ At the Buwayhid court, terms describing political relationships conjured up vanished worlds. "There was an increasing rigidity in many of the religiously sanctioned forms of proper public and private behaviour," as Mottahedeh puts it. "In private life, these forms continued to be widely used for their original purposes. But in public life, they were increasingly used not for their original purposes, but to indicate the continued respect by the user for the private application of Islamic forms." ${ }^{18}$ While some might question the neat distinction between public and private drawn here - the sources demonstrate the two realms to have overlapped considerably - my research into the forms and functions of social idioms in the Geniza corpus has convinced me that some idioms of patronage retained their original vigor, while others had been reduced to mere fossils. Yet the fossil record, too, offers valuable clues to the context that produced the organisms preserved there.

The adherence to the social and linguistic forms of patronage, then, extended well beyond the Buwayhid courts of Baghdad, Shirāz, and Rayy. It would become a pervasive feature of social life in the Fatimid realms of Egypt and Syria, and points West. It reached beyond the Buwayhid courtiers who consciously invoked Abbasid social forms even if they no longer existed in the same way; and it reached beyond Muslims who, in using the terminology of wala , conjured up a body of law even if it was no longer practiced. It appears so widely in other sources from the eleventh century to the thirteenth that one must ask where the limits of the social forms of patronage lie. Among Muslims and at court, the long afterlife of patronage relationships can be explained by the continuing need for political meaning and social coherence, depending on whose reading one follows. But that system came to encompass Jews and Christians beyond the courts and beyond the Abbasid heartland as well.

17 Sauvaget, J., Introduction to the History of the Muslim East: A Bibliographical Guide, based on the 2nd ed. as recast by C. Cahen, Berkeley, 1965, 23.

${ }^{18}$ Mottahedeh, Loyalty and Leadership, 27-28.

Al-Qanțara (AQ) XXIX 2, julio-diciembre 2008, pp. 341-382 ISSN 0211-3589 
To judge by the Geniza documents, non-Muslims adhered to the detailed etiquette of these forms of patronage sincerely and unselfconsciously. From one perspective, there is nothing surprising in this. Historians of the premodern age who have considered political relationships and social hierarchies in periods before the rise of the bureaucratic, impersonal, and abstract state, from the Roman patronate to feudalism, have frequently returned to the centrality of personal ties in political life. ${ }^{19}$ Yet each context expresses those ties and represents them differently. As the very different analyses of Crone and Mottahedeh suggest, a society's use of the vocabulary of patronage reveals much about what it values, what it chooses to retain and perpetuate from the past, how it functions in moments of crisis, how it invites non-elite groups, or those who did not enjoy the privileges of proximity to the palace, closer to the court, and how successfully it manages to convince those non-elites of the legitimacy of the social and political order. To judge by the Geniza sources, the Jews were quite convinced.

As in the literature of the Buwayhid court, personal letters from the Geniza consistently describe patrons and clients as exchanging benefit ( $n i$ ' $m a$ ), service to one another (khidma), protection (ri'āya, ināya), and nurturement (iștina $\bar{a}$ ). These exchanges ideally provoke feelings of gratitude (shukr), devotion (birr), sincerity of intent (ikhlās al-nìya and husn al-nīya), and loyalty ('ahd, dhimām). Though I have not, as yet, found evidence of Mottahedeh's sweepers and grocers using such metaphors, the Geniza corpus suggests that they were nonetheless widely understood and deployed by men and women, the literate and illiterate, courtiers, physicians, local leaders, judges, merchants, paupers, and the scribes who wrote for them - by anyone, in short, who asked for or received goods, services, or favours from anyone else.

19 See, e.g., two classic studies: Brown, P., Poverty and Leadership in the Later Roman Empire, Hanover, 2002; Bloch, M., Feudal Society, L.A. Manyon (transl.), London, 1989 [1939-40].

Al-Qanțara (AQ) XXIX 2, julio-diciembre 2008, pp. 341-382 ISSN 0211-3589 


\section{Benefaction and Thanks}

One term in particular became the basic building block of the social system: ni 'ma, the benefits bestowed on someone out of bounty, kindness, and providence. The prevalence and prominence of $\mathrm{ni}^{\text {' }} \mathrm{ma}$ in medieval Arabic literature and letters alike owed in part to its godly connotations, and one did not have to be a mu'tazili to grasp them. Just as classical Islamic thought believed God to be the foundation of the polity, since without God and the prophecy revealed to Muhammad, there would have been no state, so, too, did it regard God as the keystone that held the edifice of political etiquette and ethical conduct in place. ${ }^{20}$

$\mathrm{Ni}$ ' $m a$ 's great import in political life suggests itself in the classical Islamic tradition's association of $n i$ ' $m a$ with formal pacts and oaths. An early strain of the tradition holds that the verse "Be mindful of the favour [ni'ma] of God to you, and His covenant [mïthäq], which He confirmed [wäthaqa] with you when you said 'We hear and obey" (Q 5:7) was revealed in the context of a binding agreement drawn up among human beings: the Constitution of Medina. ${ }^{21}$ In associating the two, the tradition understands divine-human and human-human pacts alike as formal extensions of the bestowal of ni'ma: anyone who formed a binding compact enacted the beneficence ( $n i^{\prime} \mathrm{ma}$ ) of God. The creator of man was the original benefactor (mun ' $\mathrm{im}$ ) and remained the highest one; to bestow benefactions, then, was to imitate God.

$\mathrm{Ni}$ ' $m a$ as the basis for pacts — spoken and unspoken - remains a pervasive leitmotif in the Geniza documents. When, for instance, a Jew in twelfth-century Egypt petitioned a Fatimid amir for exemption from the jizya by claiming descent from the Jews of Khaybar in North Arabia, he described himself as "a Khaybari Israelite of the community of Baghdad, from among those on whom God bestowed his bene-

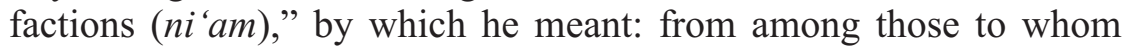

20 See especially Crone, God's Rule, 6, 10-14, who argues convincingly that Islam emerged from the moment of its birth as a theopolitical religion because, unlike Christianity and Buddhism, it was born into a stateless society. In the absence of a state, it had to create one; the new religion allowed it to do so; and consequently Islamic political thinkers always simply assumed God to be the ultimate ruler and the cornerstone of all legal, political, and ethical systems.

${ }^{21}$ Mottahedeh, Loyalty and Leadership, 45.

Al-Qanțara (AQ) XXIX 2, julio-diciembre 2008, pp. 341-382 ISSN 0211-3589 
Muhammad had granted a special pact. ${ }^{22}$ Benefactions ( $\mathrm{ni}$ ' $\mathrm{am}$ ) and pacts were seen as synonymous; bestowal by man and by God were analogous. ${ }^{23}$

The men and women responsible for the Geniza documents demonstrate an acute awareness that any bestowal of $n i$ ' $m a$ obliged its receiver to express al-shukr 'alā al-ni 'ma, gratitude for benefaction, or shukr al-mun 'im, gratitude to the benefactor. That obligation was a microcosm of social duty generally, since it motivated people to give and obliged them to receive in a particular manner, even in the absence of coercive mechanisms compelling them to do either. ${ }^{24}$ Though Arabic had developed a specialized vocabulary for expressing the dynamics of ni ' $m a$ and shukr, the basic pattern is one on which modern sociologists have also commented: Georg Simmel, for instance, argued that when legal obligations mandate reciprocity, gratitude is unnecessary, while in the absence of legally mandated reciprocity, gratitude provides "the reciprocity of service and return service, even where they are not guaranteed by external coercion." 25 Thanks, in other words, are out of place where one is obligated to render service. The question that drove Simmel to this observation is one that has consumed students of human behavior since Aristotle: why

${ }^{22}$ Rajul isra'îlì khaybarī min ahl Baghdād mim-man kāna llāh atamma 'alayhi ni 'amahu. Cambridge University Library, Taylor-Schechter (hereafter T-S) K 25.214, line 4 of the Arabic text; edited in Khan, G., Arabic Legal and Administrative Documents in the Cambridge Genizah Collections, Cambridge and New York, 1993, doc. 93.

${ }^{23}$ On the Jews of Khaybar, see Caetani, L., Annali dell'Islām, Hildesheim, 1972 [1905-26], 2.1, 7 A.H., sec. 15 (pp. 19-20), 33 (pp. 31-32); cf. 10 a. H., sec. 101 (pp. 401-4); Baron, S.W., A Social and Religious History of the Jews, New York, 1957, 3, 86, 268 footnote 16; 264-65 footnote 8, 2nd ed. On later medieval Jewish claims of descent from Khaybarī Jews and thus exemption from the jizya, see Khan, Arabic Legal and Administrative Documents, 244; cf. Goitein, Mediterranean Society, 2, 386-87; Gil, M., A History of Palestine, 634-1099, E. Broido (transl.), Cambridge and New York, 1992, sec. 255; Hirschfeld, H., "The Arabic Portion of the Cairo Genizah at Cambridge," JQR, 15 (1903), 167-81; and for a fascinating interpretation of literary representation of medieval Jews' claims to descend from the Khaybarī Jews, see Astren, F., "Explaining and Exploiting the Past: Strategies for Historicizing Islam by Karaites and Others," in M.Á. Gallego (ed.), Reason and Faith in Medieval Judaism and Islam, Leiden, forthcoming.

${ }^{24} \mathrm{I}$ offer more details in a companion to the current article, "Benefaction ( $\mathrm{Ni}$ ' $\left.\mathrm{ma}\right)$, Gratitude (Shukr), and the Politics of Giving and Receiving in Letters from the Cairo Geniza," in Y. Lev and M. Frenkel (eds.), Giving in Monotheistic Religions (in process), on which this and the next paragraph are based.

25 Simmel, G., "Faithfulness and Gratitude," in K.H. Wolff, The Sociology of Georg Simmel, New York, 1950, 387; orig Soziologie, Exkurs VIII, Die Selbsterhaltung der sozialen Gruppe (1908).

Al-Qanțara (AQ) XXIX 2, julio-diciembre 2008, pp. 341-382 ISSN 0211-3589 
human beings act benevolently and ethically even when they are not forced to do so. One need not hold a darkly Hobbesian view of the human character to recognize that continued generosity, particularly in hierarchical situations in which gifts were sent from above to below, requires some explanation. ${ }^{26}$ The ethic of $\mathrm{ni}^{\text {' }} \mathrm{ma}$ and shukr al-mun 'im was the medieval Near East's answer to this question: it granted social and political life its continuity and coherence, motivating people to deeds of generosity even in the absence of material rewards for doing so or punishments for failing to do so.

Just as the obligations incurred by one who had enjoyed ni ' $m a$ were considered required and binding, so, too, were benefactors regarded as bearing obligations toward their charges. Yet in practice, the reciprocity was so thorough that it was never quite clear whose interests were being served - those of the recipient of $n i$ ' $m a$ or those of its bestower. When one acknowledged a benefit through thanks, it began to be counted as a benefit to the benefactor, too, not through some system of presumed divine reward, but through the human calculus of ni 'ma. The Abbasid courtier Abū Ḥayyān al-Tawhīìi (d. 1023) expressed this when he wrote that excluding an aspiring loyalist from rank "is like the ingratitude (kufrān) of a follower for a benefit (ni 'ma)," on the face of it a strange analogy: so reciprocal was this kind of loyalty, he argued, that patrons could not merely enjoy their high positions without fulfilling the obligations of patronage. ${ }^{27}$ The eleventh-century Jewish merchant Ismā̄îl b. Ishāq al-Andalusī of Tyre understood this, too: in asking the long-distance trading magnate Nahray b. Nissim in Fustat for some goods to sell, he justified his request by writing, "if you were to honor me (...) with a commission or an opportunity for service (khidma), this would be a very great benefaction (ni 'ma) for me, and I believe that you would be prolonged by it." ${ }^{28}$ The bestower of $n i$ ' $m a$ stood to benefit by granting an opportu-

${ }^{26}$ The classic study of the question remains Mauss, M., The Gift: The Form and Reason for Exchange in Archaic Societies, W.D. Halls (transl.), London, 1990 [1950].

27 Hirmān al-mu'ammil min al-ra'īs ka-kufrān al-ni 'ma min al-tābi'. Abū Hayyān al-Tawhīīi, Mathālib al-wazìrayn, Damascus, 1961, 15, cited in Mottahedeh, Loyalty and Leadership, 73 footnote 34.

28 T-S 10 J 5.12, in Judaeo-Arabic, published in Gil, M., Palestine During the First Muslim Period (634-1099), (Hebrew), Tel Aviv, 1983, doc. 510. The scribe is from Badajoz; the letter discusses a shipment of Khurasani silk that was sent from Aleppo to Tyre and then Egypt and saved after delays along the way. Quotation from recto, lines 20-21.

Al-Qanțara (AQ) XXIX 2, julio-diciembre 2008, pp. 341-382 ISSN 0211-3589 
nity for service (khidma); and if such motivational rhetoric were to have any effect, it had to reflect a code of conduct vigorously enough in force to be considered binding.

At the same time, thanks for service could be renounced as a way of confirming the loftiness of the person one served. When an eleventh-century Jew named Mubārak b. Ibrāhīm b. Shemu'el petitioned

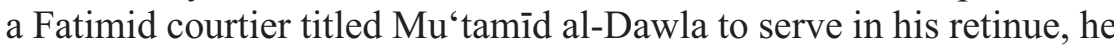
claimed to do so solely out of the desire to "be under his command ( 'inda awāmirihi), not for reward or thanks (min ghayr juz' wa-lā shukr), but out of pride in his service (ila fakhr bi-khidmatihi)." ${ }^{29}$ By renouncing material rewards and gratitude, he suggested that the opportunity to serve $\mathrm{Mu}$ 'tamid al-Dawla was its own reward, and consequently deferred to the loftiness and dignity of the courtier himself.

In the preceding quotations, both Ismā'îl al-Andalusī and Mubārak b. Ibrāhīm use the term khidma. Like ni 'ma, this term is laden with meaning, but meaning of a special type in Judaeo-Arabic documents. It is sometimes used in the usual manner to indicate service of any type, as when the otherwise unknown Yehezqel b. Ibrāhīm petitioned the mercantile magnate Abū 'Imrān Mūsā b. Abī 1-Hayy for clothing and complained that he had not left his house in two years due to weakness from hunger; he explained that he would have lodged his request with the head of the Jews ( $r a$ ' $\bar{s}$ al-yahüd), Mevorakh b. Se'adya (ca. 1079-82 and 1094-1111), but the latter was occupied with service to the ruler (mashghül bi-khidmat al-sultān), in this case the Fatimid vizier al-Afdal. ${ }^{30}$ But the word khidma frequently bore the more specific sense in which Ismā'îl al-Andalusī used it: a khidma was an opportunity for service and, as such, an opportunity for the giver to merit gratitude. Mark R. Cohen was the first to recognize this sense of the term, missing from Arabic dictionaries, in Judaeo-Arabic petitions from the poor: khidma can refer to the petition itself, as if by requesting help, the petition does the petitioned party a service by turning him or her into a patron; khidma can also refer to thanks offered the patron in the form of prayers, again as

29 T-S Ar. 39.464, lines 9-10; edited in Khan, Arabic Legal and Administrative Documents, 96.

30 T-S 13 J 28.10, in Judaeo-Arabic, unpublished; see Cohen, M.R., Jewish Self-Government in Medieval Egypt: The Origins of the Office of Head of the Jews, ca. 1065-1126, Princeton, 1980, 220.

Al-Qanțara (AQ) XXIX 2, julio-diciembre 2008, pp. 341-382 ISSN 0211-3589 
though the petitioner serves the petitioned not merely through work but by increasing his or her merit. ${ }^{31} \mathrm{~A}$ fragmentary draft of a petition to the Fatimid caliph al-Mustanșir preserved in the Geniza suggests this: "The slave of our lord, blessings of God be upon him," it opens, "kisses the ground and humbly beseeches that he be granted a service": the petitioner was asking for benefaction that would redound to the caliph's merit. ${ }^{32}$ Khidma, then, was understood to be something that served both the giver and the receiver. It reflects the amphibolous nature of $n i$ ' $m a$, from which both the giver and the receiver benefitted. But while ni 'ma was granted by the upper party in the hierarchy and enjoyed by the lower, khidma could be offered by either to the benefit of both. Khidma in this sense also preserves, again in fossilized form, the older structure of wala'': when a mawlā on manumission ceded himself and his lands to the personal protection of his patron, this was known as khidma, now in the specialized sense of commendation. ${ }^{33}$

These examples suggest that the calculus of benefit was widely understood and repeatedly invoked. Though less frequently invoked, the converse calculus was as widely understood: failure to recognize benefactions was considered a breach of major proportions. Like ingratitude toward God, ingratitude toward human patrons was called kufr al-ni ' $m a$, and the denial that any benefaction had been granted at all entailed severe consequences. Ties could be broken by denying that $n i$ ' $m a$ had ever been granted. ${ }^{34}$

One might be surprised to witness a Jewish petitioner threatening to withdraw his loyalty from the Fatimid caliph, but this is precisely what Shelomo b. Yehuda al-Fāsī, the remarkably durable leader

31 Cohen, M.R., Poverty and Charity in the Jewish Community of Medieval Egypt, Princeton and Oxford, 2005, 187-88, especially 187 footnote 51 . See also his comments on charity as a form of patronage, idem, The Voice of the Poor in the Middle Ages: An Anthology of Documents from the Cairo Geniza, Princeton and Oxford, 2005, 10-12.

32 'Abd mawlāna șalawāt allāh 'alayhi yuqabbil al-ard wa-yadra' fì istikhdämihi. T-S Misc. 28.169, line 3 of the Arabic text; edited in Khan, Arabic Legal and Administrative Documents, doc. 76. Istikhdām is not necessarily a request for employment, as Khan suggests; but cf. T-S K 16.61, line 7 (ibidem, doc. 92), an Ayyubid petition from on behalf of two young archers, in which it does refer to a request for work.

${ }_{33}$ Crone, Slaves on Horses, 49 and 237 footnote 354, citing Abū l-Faraj al-Iṣfahānī, Kitāb al-aghānī, Cairo, 1927, 12, 44.

${ }^{34}$ Mottahedeh, Loyalty and Leadership, 77: "since one acknowledged ties by accepting ni 'mah, a man could cast off ties, and in particular could cast off his allegiance, by claiming that no ni "mah had been given by the other party." 
( $\mathrm{ga}^{\prime} \mathrm{O}$ ) of the Jewish academy of Jerusalem (1025-51), did in a petition to al-Zāhir (1021-36). As ga'on, Shelomo b. Yehuda was head of the Rabbanite Jewish community of Fatimid Egypt and Syria, but during his long tenure in office he struggled to fight off rivals, incursions into his jurisdiction, and competitors for his prerogatives. The first of these rivals (we will meet the second shortly) was Yùsuf al-Sijilmāsī of Ramla, chief ( $r a$ 'iss) of the Iraqi Jewish community of Palestine, who hoped to break away from the ga'on's jurisdiction and to that end, around 1030, petitioned al-Zāhir for a rescript of investiture and some of the privileges that Shelomo b. Yehuda now enjoyed - despite the fact al-Zāhir had granted Shelomo b. Yehuda his own rescript of investiture when he acceded to office in 1025. Initiative for administrative changes in the structure of the Jewish community had to come from the Jews themselves, though the Fatimid caliphs were happy to offer decrees and ratify rescripts when asked to do so; the only way Shelomo b. Yehuda could defend himself, then, was by writing his own petition to the caliph. That petition survived in the Geniza in a later copy, from which we learn of the conflict between rivals, and of the terms in which Shelomo b. Yehuda defended his office. ${ }^{35}$

Moments in which loyalties are threatened offer rare insight into how the calculus of patronage functioned. Shelomo b. Yehuda made his case principally by reminding the caliph of the bonds of mutual obligation that the two men shared. The privileges the caliph had granted him, Shelomo b. Yehuda explained, were ni 'am, benefactions; these had created a personal, individual bond between them that could not be divided or meted out to other leaders. The privileges the caliph had granted to Yūsuf al-Sijilmāsī had "split apart" (tasha"atha) the ni "ma the caliph had granted Shelomo b. Yehuda;

35 ENA 4020.65 (formerly MS Adler 109), published in Goitein, S.D., "Congregation versus Community: An Unknown Chapter in the Communal History of Jewish Palestine," JQR, 44 (1954), 291-304, with a facsimile between pages 291 and 292; see the revised interpretation in idem, "Petitions to the Fatimid Caliphs from the Cairo Geniza," $J Q R$, 45 (1954), 30-38; and the new edition in Gil, Palestine, doc. 312, and see his discussion in ibidem, sec. 771, where he identifies the handwriting as that of Avraham b. Furāt; for the same hand, cf. T-S Ar. 30.278 and Bodleian Library, MS Heb. b 18.21, recto, in Judaeo-Arabic, published in Stern, S.M., "A Petition to the Fātimid Caliph al-Mustanșir Concerning a Conflict within the Jewish Community," Revue des Études Juives, 128 (1969), 203-22. Detailed discussion in Rustow, M., Heresy and the Politics of Community: The Jews of the Fatimid Caliphate, Ithaca, 2008, 94-99.

Al-Qanțara (AQ) XXIX 2, julio-diciembre 2008, pp. 341-382 ISSN 0211-3589 
and one could not merely split apart $n i$ ' $m a$ without risking accusations of disloyalty. ${ }^{36}$ These were not merely idle words. Shelomo b. Yehuda proceeded to take this argument to its logical extreme, threatening to withdraw his gratitude from the caliph. If the caliph granted al-Sijilmāsī the same ni 'ma he had already granted him, Shelomo b. Yehuda explained, "then the ni "ma bestowed [upon me] would be no ni 'ma at all." ${ }^{37}$ If no ni ' $m a$ had been granted, he was within his rights to sever the relationship. To reinforce this threat, he invoked the investitures that the caliph's father, grandfather, and great-grandfather had granted his predecessors, comparing their loyalty invidiously with the current caliph's promiscuity: "The pure excellencies have made grants in many rescripts to many heads (of the Jews) over the course of time, a fact of which the archives offer proof, but they have never made any one of them a partner in what they bestowed on them." This seemingly indictive sentence was followed by a quasi-formulaic phrase likely to convince the caliph of Shelomo b. Yehuda's loyalty to the regime despite the accusations: "for the decree of the Government, may God bestow glory upon its victories, is laid down." 38

Indeed, a severed relationship is an inexplicably bold thing for a dhimmi dependent like Shelomo b. Yehuda to threaten, and before a caliph no less. In doing so, he had the force of several sets of obligations in his favour: his personal relationship to the caliph, which the caliph also had to treat seriously or risk his legitimacy in the eyes of the Jewish community; the dhimma (pact) between Muslim rulers and their non-Muslim subjects, which by definition entailed mutual obligations, not just those of the subalterns toward their rulers; and a common store of political vocabulary, which allowed Shelomo b. Yehuda to express these ideas succinctly yet comprehensibly, with all the implications of reciprocity that the word ni 'ma entailed. The use of coded language, in other words, loaded the petition with particular connotations intended to conjure up the bonds of loyalty between political men.

36 ENA 4020.65, lines 25-27. It may be that the verb tasha " $u$ th, "splitting apart", should be tasha " $u b$, "scattering", a possibility for which I am indebted to Devin Stewart. Indeed, the Judaeo-Arabic copyist was apparently faced with the unpointed chancery hand of the original and may have read one for the other.

37 ENA 4020.65, lines 5-6.

38 ENA 4020.65, lines 27-30.

Al-Qanțara (AQ) XXIX 2, julio-diciembre 2008, pp. 341-382 ISSN 0211-3589 
$\mathrm{Ni}$ ' $\mathrm{ma}$, then, was the most basic element in exchanges of protection and loyalty, and its consequences were profoundly understood and broadly invoked in political relationships. But if ni'ma shaped all bonds of patronage, ties between benefactors and receivers could be expressed in a number of different ways, using a variety of metaphors.

\section{Patronage and its Metaphors}

Three distinct images evoking patronage recur in the Geniza material: 'ināya, providential care, as God's for mankind; ri 'āya, tending, as one does a flock; and iștina ', nurturing or rearing, as one offers a child.

\section{'Ināya}

'Ināya, like ni 'ma, has quranic roots and human consequences; in works of philosophy, God's providence is called al- 'inäya al-ilähiya, while in the Sufi lexicon, al- inaya means divine benefaction or generosity. Like ni ' $m a$, it, too, was a form of benefaction in exchange for which one was obligated to render one's loyalty to the benefactor. The root on which it is based means to concern or disquiet, but ināya came to mean attention or solicitude of a special type. The term might, then, be translated as patronage without doing much violence to its original sense.

When, for instance, in 1037-38 the distinguished and extremely old Hayya b. Sherira (d. 1038), ga'on of one of the rabbinic academies of Baghdad and spiritual leader of Iraqi Jewish congregants all over the Mediterranean, learned of a plot against one of his appointees, Sahlān b. Avraham, the head of the Iraqi congregation of Fustat, he wrote to Sahlān to advise him how to act. The first thing he explained was that Sahlān should draw on the help of an old friend and ally at the Fatimid court in Cairo, the Qaraite courtier Abū 1-Nașr al-Faḍl (Hesed) al-Tustarī. "I shall write to (al-Tustarī)," Hayya promised Sahlān, "and ask him to tell me about the situation with all its facts and to direct his solicitude ( 'ināya) toward you." 39 Thus did

${ }^{39}$ Cambridge University Library, Jacques Mosseri Collection, Ia 5 (L 2), in Ju-

Al-Qanțara (AQ) XXIX 2, julio-diciembre 2008, pp. 341-382 ISSN 0211-3589 
Hayya call upon providential care for his charge at a great distance; it was al-Tustarī's loyalty toward Hayya that enabled him to do so, and it was al-Tustarī's high rank that allowed him to watch over Sahlān and protect him. Likewise, when Abū Sa'īid b. Tāariq, a Jewish trader from Ifrīqiya living in Palermo, wrote to his brother Abū 1-Barakāt in Fustat around 1060, he extended greetings to their trade associates, and specifically those from whom his brother might expect loyalty, referring to them as "all those whom your solicitude ( ināya) encompasses and whom your patronage ( $r i$ 'aya) surrounds." 40 Similarly, when some time after 1060 another pair of brothers learned that the man to whom their sister had been betrothed for years had suffered severe financial losses, they attempted to break the engagement by sending a petition to the head of the Jews ( $r$ ' $\bar{s}$ s al-yahüd or nagid) of Fatimid Egypt and Syria beseeching him, in his capacity as chief magistrate, to annul the engagement: "the slave (mamlük) requests intervention from the lord (mawlā) in (his) patronage ( in $\bar{a} y a)$," they wrote, reminding him —out of the pure pragmatics of self-interestof his obligations toward them. ${ }^{41}$

As I have suggested above, one of the chief difficulties in reading material like this lies in knowing how much weight terms carry. Even if one establishes that terms are technical terms, are they being used in a debased sense, as mere formulary? This is true, for instance, of the metaphor of "slave" (mamlük) and "master" (mawlā): in the petition I have just quoted and others, the terms are almost too pervasive and seemingly banal to bear analysis. But their omnipresence in petitions - which merely by their submission made petitioners the slaves of those whose favour they requested - reflects the importance of the informal type of patronage relationship after the first three Islamic centuries. More importantly, it reflects the tendency of political relationships to be expressed as individual ties. The use of formulaic lan-

daeo-Arabic; edited in Chapira, E.D., "Lettre du Gaon Hai," Revue des Études Juives, 82 (1926), 327; and Gil, M., In the Kingdom of Ishmael, (Hebrew), Tel-Aviv and Jerusalem, 1997, doc. 41. For a nearly complete translation to English see Rustow, Heresy and the Politics of Community, 299-301.

40 T-S 13 J 26.10, in Judaeo-Arabic, lines 28-29 (jamī' man tashmiluhu 'ināyatuka wa-tahututu bihi ri 'àyatuka). Goitein's edition published on-line by the Princeton Geniza Project (www.princeton.edu/ geniza) (hereafter PGP); see idem, Mediterranean Society, 1, 274; also edited in Gil, In the Kingdom of Ishmael, doc. 830.

${ }^{41}$ Wa-l-mamlūk yastashfa' 'u min al-mawlā fì l-'ināya. ENA 1822a 4, in Judaeo-Arabic, lines 9-10. Goitein's edition published on-line by the PGP. 
guage was part and parcel of the importance of individual ties: in petitions, the proper use of formulaic language delivered or denied the petitioner his or her success; adherence to proper etiquette in and of itself expressed the petitioner's sincerity and the worthiness of his or her case for redress. This reflects the capacity of language to shape social ties - palpable in the sources I have read and likely as palpable for those who wrote them and for whom they were intended.

But once these terms had become old and worn - or as Nietzsche put it, once the coins of metaphor had lost their embossing - the tendency of terms of patronage to harden into formulaic language reflected a different sort of linguistic formalism, the one to which I referred above as the capacity of set phrases to carry echoes and resonances from the past. ${ }^{42}$ The same tendency also appears in the way honorifics hardened into permanent titulature. ${ }^{43}$ More broadly, in epistolary form, linguistic formalism appears in the pervasiveness of the petition as a genre of letter writing, from paupers to amirs.

Nor did a petition have to be of a formal or public nature to reflect this type of linguistic formalism: most of the petitions preserved in the Cairo Geniza were sent by and to private parties regarding personal matters. Yet they adhere scrupulously to a particular structure, and even to particular phrases. That does not mean that the form and formularies of the documents were debased or devalued, mere form-letters into which the specifics of the case were inserted. With Mottahedeh, I am inclined to understand the use of particular constructs in set or formulaic phrases as demonstrating not the lack of weight to be accorded to a particular term, but its pervasive meaning; "by their flattery," as he put it, "they show its importance." 44

42 Mottahedeh attributes this to the linguistic formalism of "a scripturalist tradition in which an immutable text lies at the heart of religious study," since words continue to carry quranic resonances even when used in non-religious contexts (Loyalty and Leadership, 9), but the phenomenon may be a purely sociolinguistic one: compare the origins of the modern Italian informal greeting ciao in the gallant and formal greeting in Venetian dialect, "sc'ia[v]o" (standard Italian schiavo [vostro]), "[your] slave."

${ }^{43}$ Balog, P., "Pious Invocations Probably Used as Titles of Office or as Honorific Titles in Umayyad and Abbasid Times," in M. Rosen-Ayalon (ed.), Studies in Memory of Gaston Wiet, Jerusalem, 1977, 61-68; see further Rustow, Heresy and the Politics of Community, 76-86, with reference to earlier studies.

44 Mottahedeh, Loyalty and Leadership, 93.

Al-Qanțara (AQ) XXIX 2, julio-diciembre 2008, pp. 341-382 ISSN 0211-3589 
$R i ` \bar{a} y a$

$R i{ }^{\prime} \bar{a} y a$, the special care of the shepherd toward his flock, also bears a dual usage as plain or technical language, though in this case, distinguishing between the two is not difficult. $R i$ ' $\bar{a} y a$ can indicate simply supervision and oversight, as when letter-writers urge mail carriers (often their friends) to exercise special care ( $\left.r i^{\prime} \bar{a} y a\right)$ in ensuring that letters reached their destinations. ${ }^{45}$ But the word's origins in the verb "to tend" also lent it special connotations of guardianship, protection, and patronage, with even more subtle shades of meaning in Judaeo-Arabic. ${ }^{46}$ When, for instance, Abū Zikrī, a young Jewish physician in the retinue of the Ayyubid sultan al-Malik al-'Azīz, wrote to his mother, Sitt al-Ghazal, to ask her to host a friend and his wife, he urged her to accommodate them "with the benefaction (ihssān) of your support and your patronage (ri'āya)." 47 The term could also invoke less fleeting and more binding kinds of patronage: when the Jerusalem ga'on Shelomo b. Yehuda confided in a letter of 1030 that he had been betrayed by some of his erstwhile supporters, he complained about one man in particular who he had hoped would help him "with a favour (al-jamil). As if it is not enough that he did not help me," he lamented, the man "was in the palm of my enemy's hand (fi kiffat al-ghayr), and supported me in keeping with the saying, 'then the people of the land weakened the hands of the people of Judah, and harried them while they were building' [Ezra 4:4]." He added: "I know that he is patronizing that group (annahu yura' ' $\bar{c}$ al-qawm), because they support him." 48 The implication was that the

45 See, e.g., T-S 10 J 5.6 + TS 20.113, in Judaeo-Arabic, a letter of 1100 from the Qaraites of Ascalon on the fate of captives from the Crusade conquests in Palestine, expressing the wish that the letter arrive fi murā'at al-rasül, edited in Goitein, S.D., Palestinian Jewry in Early Islamic and Crusader Times in Light of Geniza Documents, J. Hacker (ed.), (Hebrew), Jerusalem, 1980, 240-50, and Gil, Palestine, doc. 577, and translated to English in Goitein, Mediterranean Society, 5, 372-79. See also T-S 16.27, in Judaeo-Arabic, line 12; Goitein's edition published on-line by the PGP. The verb $r \bar{a}^{\prime} a$ can also mean "to heed" (see, e.g., Bodl. MS Heb. b 18.21, verso, line 4).

46 This meaning is not reflected in the Arabic dictionaries I have consulted; cf. also Blau, J., A Dictionary of Mediaeval Judaeo-Arabic Texts, Jerusalem, 2007, s.v. R'Y III (253).

${ }^{47}$ Min ihsāniki l-nașr wa-l-ri āya. Bodl. MS Heb C 50.24, in Judaeo-Arabic; Goitein's edition published on-line by the PGP. The quotation is from line 6 .

48 T-S 13 J 19.16 and T-S $13 \mathrm{~J} 16.15$ (the second shelf-mark is a later copy of the first), in Judaeo-Arabic, published in Baneth, D.Z., "A Letter from Shelomo b. Judah, 
group would not have lent Shelomo b. Yehuda's rival their loyalty were not the rival extending them his patronage. $R i$ ' $\bar{a} y a$ was, then, the obverse of loyalty: patrons meted out the first in exchange for the second.

This is even clearer in a letter by the second pretender to Shelomo b. Yehuda's post, the highly ambitious Natan b. Avraham, who usurped his position outright for four years. In Jerusalem in autumn, 1038, Natan b. Avraham arrogated the ga'on's title and began using it to sign his correspondence; he continued to exercise gaonic titulature and privileges until autumn, 1042, appointing judges, writing responsa, and dispensing titles to his followers. One reason he got away with it for so long was that he had allies at the Fatimid court: by now it was no secret that the stability of a ga'on's tenure in office hinged on his cultivating allies in Cairo; only in this way might he assure himself of obtaining rescripts of investiture from the caliph's chancery. ${ }^{49}$ Armed with this information, Natan b. Avraham set about assiduously cultivating the loyalty of the grandees of Fustat; one of these was al-Tustarī, whom we met above. Acutely aware of al-Tustarī's centrality to his ambitions, Natan b. Avraham closely followed his progress through the Fatimid hierarchy. In 1040, he learned of al-Tustarī's appointment as administrator $(k \bar{a} t i b)$ of the military commander (amīr al-juyūsh) of Palestine, the Turkish general and manumitted slave Anushtekīn al-Duzbarī. Natan b. Avraham wasted no time in reporting to his allies in Fustat the fact that their powerful patron at court had been made more powerful. Al-Tustarī "was appointed a kätib of the amīr al-juyüsh," Natan b. Avraham announced, "and he is our patron (wa-huwa murā' $\bar{l}$ lanā), heeding what we direct his way (mumtathil mã nukhätibuhu fihi)." " ${ }^{50}$ Ri 'ãya was the term of

Gaon of the Jerusalem Yeshiva, to an Anonymous Party in Fustat," in Studia orientalia memoriae D.H. Baneth dedicata, Jerusalem, 1979, 1-16, and in Gil, Palestine, doc. 92 (cf. both their translations, and cf. Blau, Dictionary, s.v. R'Y III [253]).

49 On the gaonic schism of 1038-1042, see Cohen, M.R., "New Light on the Conflict over the Palestinian Gaonate, 1038-1042, and on Daniel b. 'Azarya: A Pair of Letters to the Nagid of Qayrawan," Association for Jewish Studies Review, 1 (1976), 1-37; Gil, Paestine, 1, secs. 870-84; Ben-Sasson, M., The Emergence of the Local Jewish Community in the Muslim World: Qayrawan, 800-1057, (Hebrew), Jerusalem, 1997, 368-72; Gil, In the Kingdom of Ishmael, sec. 48; and Rustow, Heresy and the Politics of Community, $302-22$.

50 T-S AS 157.232r + T-S AS 157.231r, in Judaeo-Arabic; published in Gil, M., The Tustaris, Family and Sect, (Hebrew), Tel Aviv, 1981, doc. 6, with facsimile.

Al-Qanțara (AQ) XXIX 2, julio-diciembre 2008, pp. 341-382 ISSN 0211-3589 
choice, then, to describe patronage relationships in which the element of hierarchy was well defined; it matters little that Natan b. Avraham was an exceedingly insincere pretender whom Shelomo b. Yehuda described at the height of the conflict as "riding around on his donkey all day long" in imitation of the 'ulamä', "going from gate to gate and beseeching (people), Help me, oh help me, and I shall respond to your (legal) queries," or that he was entirely disingenuous in his cultivation of al-Tustarî's patronage. $R i$ ' $a y a$ 's place in social relations was well enough understood that Natan b. Avraham had only to invoke it to convey his meaning.

If $r i$ ' $\bar{a} y a$ was the term of choice to describe hierarchical relationships, the hierarchical implications of the term might accurately reflect the relationship itself or might merely follow on the terms used to lodge a request. In this way language created relationships as much as the converse. Likewise, men more nearly equal in station could summon up the language of patronage to soften requests they made of each other. Yosef $b$. Shemarya, a Jewish judge of Barqa, turned an ally into a patron in this way, at least for immediate rhetorical purposes. Sometime in the last third of the eleventh century, the judge spent the winter in Alexandria and decided to return home to Barqa rather than complete his pilgrimage to Jerusalem. Before heading back West he wrote to the shipping magnate Nahray b. Nissim to settle some business before Nahray himself headed to Jerusalem. The judge asked Nahray to repay a debt of two dinārs, and immediately attempted to soften his request with flattery: "for you are my protec-

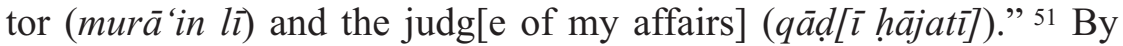
using the term mura $\bar{a} i$, Yosef $b$. Shemarya conjured up a set of associations intended to manage Nahray's reaction: because you are my patron and protector, you will indulge my little request and not become angry about it; it would be so unlike you, in your magnanimity, to act illiberally toward me.

One does wonder, in reading these letters, which terms reflect some mixture of sincerity and formalism and which are mere empty

${ }^{51}$ Li-annahu murā' lī wa-qāẹ [ī hājatī] wa-qad faraja 'annī fì hādhā l-waqt bi-hādhā shāy'. New York, Library of the Jewish Theological Seminary of America, Elkan Nathan Adler collection (henceforth ENA) 2805.13, in Judaeo-Arabic. A.L. Udovitch's edition published on-line by the PGP. See also Goitein, Mediterranean Society, 2, 274 (who translates part of the following section). 
markers. Below I will suggest that this question is misleading; for the moment one need only think of our own terms of etiquette to understand that they can be both at once. Yet by the late eleventh century, at least in Judaeo-Arabic, some terms had clearly come unmoored from the social contexts in which they had originally harboured and flourished. And this tendency of affective idioms to harden into formulaic phrases finally extended to the most tender, intimate, and, ultimately, bastardized of terms for patronage: iștin $\bar{a}^{\prime}$, a term literally indicating favour, kindness, or conferring or receiving benefit, but by extension, nurturing or fostering a special protégé.

\section{Iștina $\bar{a}^{*}$}

Istin $\bar{a}^{\prime}$ is an important term in Mottahedeh's anatomy of the social world of ghilmān and kuttāb alike: it is the very substance of networks of patronage. It "is a surprisingly formal and serious relationship," he writes; "a man expected from his protégé (musțana 'or șani" or sani' 'ah) not an easy gratitude and affection, but a lifelong commitment of sizable dimensions. To say 'he is my sani 'ah' meant he is the person I have reared, educated, and trained well,' and the obligation to such a patron was like the obligation to a parent, except that it was neither inherited nor transferable by legacy." 52

Of the numerous telling anecdotes Mottahedeh musters on iștina the most striking comes from the continuation of al-Tabarî's history by Muhammad b. 'Abd al-Malik al-Hamadhānī (d. 1127), a courtier and chronicler under the Abbasid caliph al-Mustazhir (1094-1118), a single volume of which has survived covering the years 295-487 A.H. Al-Hamadhāni recounts the death of the Buwayhid vizier Abū Muhammad al-Muhallabī (d. 352/963), which left his protégé, the Christian clerk $(k \bar{a} t i b)$ and physician Abū 1-'Alā' 'Īsā b. al-Ḥasan b. Abrūnā, without a patron. So unprotected was Ibn Abrūnā that al-Muhallabī's rivals tortured him to find out where al-Muhallabī had hidden his wealth before dying. When they threatened to kill Ibn Abrūnā, he proclaimed: "Shall I be Ibn Abrūnā, the physician and phlebotomist plying his trade on the street for a [measly] fee of one and a half dāniqs, whom the vizier Abū Muhammad took and patron-

52 Mottahedeh, Loyalty and Leadership, 77.

Al-Qanțara (AQ) XXIX 2, julio-diciembre 2008, pp. 341-382 ISSN 0211-3589 
ized (iștana 'an $\overrightarrow{)}$ ) and made his private secretary (kätib sirrihi), and who has become known as one in his service (bi-khidmatihi) - and inform people of a treasure he has stored up for his son? By God, I would not do so even if I were to perish." So durable were the bonds of iștinā ' that 'Īsā wished to be known after his patron's death as having been discovered and made by him; and so convincing was this argument to the officials who succeeded al-Muhallabi that they freed him and took him into their own service. ${ }^{53}$

Isțin $\bar{a}$ ' was, then, a way of creating political ties and perpetuating a political class; those who failed to bestow it upon their chosen subordinates were less likely to end their careers alive, and conversely, the chronicles are filled with stories of rulers and commanders saved from death or defeat by ghilmān whom they convinced should be loyal toward them. ${ }^{54} \mathrm{Ibn}$ Khaldūn, notoriously inclined to filter even the most urban and deracinated of Arab histories through the experience of the desert, saw istin $\bar{a}^{\prime}$ as a later but hardly attenuated form of the ancient fictive kinship through which the Arabs assimilated strangers to their tribes by walä'. "When people (of group feeling, 'asabiyya) adopt as followers (istana 'a) people of another descent or take slaves ( 'ibidd $\bar{a})$ and clients (mawāl $\vec{l})$ into servitude and enter into close contact with them," he wrote, echoing the etymological meaning of wala", to be near, "as we have said, the clients and followers (muștana ' $\bar{u} n$ ) share in the group feeling of their masters and take it on as if it were their own group feeling." ${ }^{55}$ Thus Ibn Khaldūn held urban and evolved (or devolved, as he might have seen them) forms of patronage to preserve, even in fossilized forms, the social patterns of tribal society. In the court chronicles of the tenth and eleventh centuries, $i s ̦ t i n \bar{a}$ ' is of another species entirely, worlds away from tribal so-

53 Muhammad b. 'Abd al-Malik al-Hamadhānī, Takmilat tārīkh al-Ṭabarī, A. Kan'an (ed.), Beirut, 1961, 185; quoted in Mottahedeh, Loyalty and Leadership, 90 (I have altered his translation slightly).

54 Mottahedeh, Loyalty and Leadership, 91 (Ibn al-Zayyāt, from al-Tanūkhī, Nishwār al-muhāọdara wa-akhbār al-mudhākara); 88-89 (Rūzbahān and Mu'izz al-Dawla, from al-Miskawayh, Tajārib al-umam; Jalāl al-Dawla, from Ibn al-Athīr, al-Kāmil fī l-tārīkh; 'Izz al-Dawla, from al-Miskawayh, Tajārib al-umam); but cf. ibidem, 40-41 (al-Muqtadir, from al-Miskawayh, Tajārib al-umam).

55 'Abd al-Rahmān b. Muhammad ibn Khaldūn, The Muqaddimah: An Introduction to History, F. Rosenthal (transl.), New York, 1958, 1, 276 [1, 245] (my translation differs slightly); cited in Mottahedeh, Loyalty and Leadership, 89-90.

Al-Qanțara (AQ) XXIX 2, julio-diciembre 2008, pp. 341-382 ISSN 0211-3589 
ciety; it refers to elective clientage, to the caliphs', viziers', and amirs' relationships to the secretaries and the palace guards of whom they expected loyalty (even if they did not always receive it). And in the chronicles it recurs as the most intimate and durable form of patronage among men at court: fostering a protégé was like raising one's own child.

All the more surprising, then, that in the Judaeo-Arabic correspondence, the term appears in this sense exceedingly rarely, even in letters describing the relationships of merchants to their apprentices and great scholars to their disciples. Both traders and the Jewish 'ulamā' apprenticed their sons to one another; the opportunities for this kind of istina $\bar{a}^{\prime}$ were abundant. Yet its sparse appearances in the sense of patronage in the Geniza sources lead one to conclude either that the word was reserved for courtly patronage, or even for ghilmān and other military and bureaucratic fosterage; or that it took another turn as the courts of Iraq and Iran receded from view.

I might have expected to find it, for instance, in a business letter regarding a long list of expensive textiles and clothing that the trader Mūsā al-Tāhirtī sent to Sahl al-Tustarī, the eldest brother of a trading clan and the father of the Tustari mentioned above, writing about a common business associate, Abū Zikrī Yehuda, one of the chief merchants of Qayrawān and a grandee closely connected with both the Tāhirtī merchants and the Zīrid rulers of Ifrīqiya. Abū Zikrī had asked the Tustarīs to arrange some purchases for him in Egypt and sent his ghuläm to fetch the items - the mercantile elite, too, kept ghilmān, yet another opportunity to cultivate ties of fosterage (istina $\bar{a})$. Then the Tustarì brothers had gone and asked the ghuläm a favour that they now worried stretched the bonds of Abū Zikrī's generosity: imposing on a man's ghuläm was like imposing on the man, and to be avoided. Mūsā al-Tāhirtī therefore took it upon himself to reassure al-Tustarī that "the ghuläm, my lord, was not terribly inconvenienced," and even if he had been, Abū Zikrī would not have minded, for "the man seeks your friendship (widad)... and a connection with you (through marriage); he wants to profit from your high position (jāh) and have your advice in his undertakings." Abū Zikrī didn't mind, in other words, because he wanted Sahl al-Tustari to feel indebted to him. So great was his desire to strengthen his connection with al-Tustari that if he "had a son fit to apprentice in your firm (yakhdim quddämakum), he would have been honored by this" and sent him to them immedi- 
ately. ${ }^{56}$ An apprenticeship was like adoption; surely Abū Zikrī might have used the term istin $\bar{a}^{\prime}$ regarding the apprenticeship of his putative son with colleagues, if not with his very ghulam. Yet he did not.

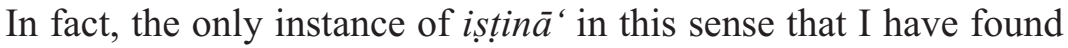
in the corpus of more than four thousand documents I have searched ${ }^{57}$ appears in a letter from a different Abū Zikrī, this one the young Jewish physician at the court of al-Malik al-'Azīz whom I mentioned earlier. In 1196, Abū Zikrī wrote to his father, the judge Eliyyahu b. Zekharya, explaining that he was unable to leave Jerusalem on order of his superior, the sultan, who was in Damascus; he therefore asked his father to send him some medicines he could not acquire himself and also sent greetings to some physician colleagues in Fustat. In particular, he sent good wishes to a mentor, a certain Abū l-Mukāram, "the father of my brother al-Rashīd Abū 'Alī. I have sent him a (separate) letter in which I thank him for the kindness of his benefaction and patronage ('ala jamìl șan 'ihi wa-iștinā ihi)." 58 The insistence with which Abū Zikrī uses both șan ' and iștināa suggests that he knew precisely what he was doing. The medical profession was usually passed from father to son; Abū Zikrī's father was a physician, but like scholars and scribes, he aimed to augment his son's professional capital and contacts by sending him to apprentice with a colleague. Abū Zikrī now thought of his mentor's son as a brother and of his mentor as having nurtured him adoptively. Can it be Abū Zikrī's years of contact with the Ayyubid court that had taught him to express the tie in terms of istina $\bar{a}^{-}$? And is it a mere accident of preservation that such ties are not expressed in these terms more frequently in the correspondence of the Geniza?

In fact, the traders I discussed above had just as much contact with the courts of amīrs and caliphs as Abū Zikrī, and they were surely aware of this kind of fosterage as an important type of political tie. Nor is it the case that isțina $\bar{a}^{\prime}$ and related words do not appear in the

56 T-S 12.133, in Judaeo-Arabic, recto, lines 12-14; edited in Gil, The Tustaris, 69-75, with facsimile; and idem, In the Kingdom of Ishmael, doc. 128; translated to English in Goitein, S.D., Letters of Medieval Jewish Traders, Princeton, 1973, 74-79.

${ }^{57}$ I searched the database of the PGP, which contains roughly four thousand documents, including many of those published in the monographs cited above as well as unpublished editions by S.D. Goitein, A.L. Udovitch, M.R. Cohen, and others.

58 T-S $13 \mathrm{~J}$ 22.24, in Judaeo-Arabic, verso, line 18; edited in Goitein, Palestinian Jewry, 322-26.

Al-Qanțara (AQ) XXIX 2, julio-diciembre 2008, pp. 341-382 ISSN 0211-3589 
corpus at all. On the contrary: they appear abundantly, but in another meaning; and in the transformation of istin $\bar{a}^{\prime}$ lies another clue to the evolution of patron-client ties outside the world of the courts.

A Jewish notable writing from Alexandria in autumn 1200, for instance, used the term in passing in a letter describing the shortage of wheat and water in the city, a crisis preceding the great famine of in Egypt in 1201-2, in ordering a staggeringly large quantity of wheat from Fustat to feed both his family and the community in his care. $\mathrm{He}$ instructed his addressee to send the wheat in care of a Muslim messenger in order to ward off the evil eye (i.e., robbery) "from the gentiles, who menace the Jews daily with plunder" and specified that to evade a high toll, the Muslim messenger should "rely on his high position (jāh) to enter the city," that is, should make it known that he has connections in government. ${ }^{59}$ The writer, furthermore, unwilling to risk an ineffective appeal, lodged his request in the formal register of petitions; his resort to this element of written formalism suggests the desperate straits in which he found himself. "May the beneficent presence (al-hadra al-mun 'ima)," he flattered his addressee, "(send) his slave ten irdabbs (of wheat; the letter is lacunose here)... The slave is importunate: all year his house has been empty, with no wheat in it, despite his large family and numerous followers. May God, may he be exalted, extend remedy for the affliction and benefit (mann) to His servant by means of your patronage (iștina $\overline{)}$ ) and protection (iftiqād)." ${ }^{60}$ God would extend his providential care, and the addressee in Fustat would be the executor of God's will in his patronage (istinin $\bar{a}$ ), protection (iftiq $\bar{a} d$ ), and his role as benefactor (mun 'im). Though use of istin $\bar{a}^{\prime}$ here bears the overtones of special oversight and protection that it also bears in cases of true clientage, it also hints

59 ENA NS 19.10, in Judaeo-Arabic and Hebrew, lines 3-10; edited in Frenkel, M., The Compassionate and Benevolent: The Leading Elite in the Jewish Community of Alexandria in the Middle Ages, (Hebrew), Jerusalem, 2006, doc. 16; Goitein's edition also published on-line by the PGP; see also idem, Mediterranean Society, 4, 238-39 (partial translation), 437 footnote 92 (on the dating).

60 The words in italics in the translation (in quotation marks below) are in Hebrew. Fa-tafaddala al-hadra al-mun 'im [a ... ] li-mamlükihä 'ashara arädib [qamh] wa-ya'rifu al[-shaykh inna] al-mamālikk li-[...] an yusallimahu fa-inna l-mamlūk [mu]lhif kulla sanatin bay[t]uhu färighun mä fïhi qamh ma'a kuthrat 'à'ilatihi wa-atbā'ihi wa-l-lāhu ta '(ālā) "hiqdim refu'a la-makka" wa-mann 'alā al-khädim bi-iștinā 'ihä wa-iftiqādihā. ENA NS 19.10, verso, lines 5-8; see Goitein's explanation of these lines, Mediterranean Society, 2, 437 footnote 100 .

Al-Qanțara (AQ) XXIX 2, julio-diciembre 2008, pp. 341-382 ISSN 0211-3589 
at the fact that in Judaeo-Arabic the word tended to be used principally in the context of requests. While this writer, understanding the roots of the term, connects human patronage with the divine sort, most of the other Judaeo-Arabic letters in which I have found it were evidently unaware of those roots and used the word instead in a stereotyped and formulaic fashion.

Indeed, apart from the single example I cited above, among the thousands of documents I have searched, isțina $\bar{a}^{\prime}$ appears only as a piece of motivational rhetoric intended to convince the reader to perform some favour for the writer. In writing to the magnate Nahray $b$. Nissim, the trader Mașliah b. Yehuda of Alexandria asks for help retrieving some money that his associates in Fustat still owed him, and phrases his request this way: "you would do me a good deed (of the kind that God rewards; mathwaba), and truly I would be among those who thank you, and verily you would bestow kindness on me (wa-la-yaștani 'nì), and you would proffer your benefaction (jamil) to me as you have proffered your benefaction and favour $(f \bar{a} d l)$ on others." ${ }^{61}$ The term had, it appears, been debased to the point where it served in formulaic contexts and meant, simply, conferring a favour.

Those contexts were principally petitions for charity and other written requests for aid. Many of them are addressed to the heads of the Jews (ru'asä' al-yahüd or negidim) of Egypt and Syria, a significant fact since, like petitions to the Fatimid chancery, letters to negidim followed increasingly stereotyped formulae that were not unrelated to chancery formulae themselves. One of the major responsibilities of the negidim was tending to the poor and needy and granting them aid, and they did so not merely as representatives of the community in the abstract, but as private individuals. We saw a hint of this tendency toward personal relationships earlier, when the desperate Yehezqel b. Ibrāhīm found the nagid Mevorakh b. Se'adya occupied with khidmat al-sultān and lodged his request for help with Abū 'Imrān Mūsā b. Abī l-Hayy instead. The abundant evidence the Geniza has preserved relating to private charity reflects the individual quality of leadership outside the public one of the communal dole, a

61 Wa-ya 'mil fiyya mathwaba wa-la-nakūn lahu min ba'ḍ al-shākirīn wa-la-yașțani 'nī wa-li-yasbiq jamīlahu 'alayya ka-mā sabaqa jamìlahu wa-fädlahu 'alā ghayrī. T-S $10 \mathrm{~J}$ 12.21, in Judaeo-Arabic, right margin, lines 6-11; published in Gil, In the Kingdom of Ishmael, doc. 762; Goitein's edition also published on-line by the PGP. 
phenomenon that can be explained through the very dynamics of patronage under discussion here: the nagid was personally responsible for individual members of the community. ${ }^{62}$ Indeed, even the highest rulers bestowed public works not in the name of the state but as individuals, and their subjects were expected to express their gratitude - and did so - not to an abstract state but to the individual donor. ${ }^{63}$

But even when petitions were addressed to the nagid in a private capacity, most of those that came from the poor were penned by professional scribes who worked on behalf of the Jewish community as a collectivity; and scribes knew that requests for patronage were more effective when they followed a certain protocol. They used and reused phrases built around isțina $\bar{a}^{\prime}$; this word had entered the range of specialized and stylized vocabulary and become part of the scribe's rhetorical arsenal. In short, it assumed a technical meaning in Judaeo-Arabic, one illustrated by the following examples.

An undated petition for help from the eleventh or twelfth century, written in a calligraphic, surely professional, hand (perhaps that of a legal court scribe), asked its recipient (perhaps a judge in another rabbinical court) to help the bearer sell a quantity of cheese; "and may he treat him according to the liberality (iștina 'ihi) that is known among everyone." ${ }^{64}$ Likewise, a woman petitioned the ra'is al-yahüd Shemu'el b. Hananya (1140-59) to help her husband pay the jizya, which he had been imprisoned for avoiding; the family was now starving, and the scribe who wrote a petition on her behalf asked that the nagid honor her request "out of kindness ( $f i$ iștinā $)$ " to herself and her children. ${ }^{65}$

Nor is it merely the handwriting of scribes that suggests that istin $\bar{a}$ ' had entered the store of terms commonly used among professionals. Their petitions use other formulaic phrases borrowed from the pool of rhetoric normally found in appeals to the Fatimid chan-

62 On the nagid's role as helper of the poor, see Goitein, Mediterranean Society, 2, 36-38; on the Jewish poor and the distinction between public and private charity, see Cohen, Poverty and Charity, 189-242; see also 174-88.

63 Goitein, S.D., "Minority Selfrule and Government Control in Islam," Studia Islamica, 31 (1970), 102; Mottahedeh, Loyalty and Leadership, 77-78.

64 Wa-yaf'al ma'ahu hasab iștinā'ihi al-ma'rüf ma'a kull ahad. T-S $10 \mathrm{~J}$ 9.17, in Judaeo-Arabic, lines 9-10; Goitein's edition published on-line by the PGP.

$65 F \bar{l}$ iștinā' al-'abda wa-atfälihā (on the term 'abd in these petitions, see below). Philadelphia, University of Pennsylvania, Center for Advanced Judaic Studies Library, Halper 379, in Judaeo-Arabic; line 12. Goitein's edition published on-line by the PGP. 
cery. When the pauper Ibrāhīm of Sunbāt wrote to the head of the Jewish community in Fustat for help for his family, the provincial scribe writing on his behalf styled him "the slave" (al- 'abd) and the recipient "your excellency the nagid" (hadrat ha-negidut in Hebrew, echoing the Arabic honorific al-hadra, the Presence). He introduced the main body of the request with another standard marker in chancery petitions, the phrase "the slave (...) makes it known to his excellency," 66 and employed the following piece of rhetoric in closing: "How fitting it would be for you to confer protection (istina $\bar{a}$ ) on me and show mercy to me and my children ( $m \bar{a}$ awlähā fi istinā 'ihi wa-l-rä'fa lahu wa-li-atfälihi)." ${ }^{67}$ The latter phrase reads as lofty, but in fact it is a common one, mechanical and stereotyped. It appears nearly verbatim in another petition, this one from the widow of a cantor named Ben Naḥman to the ra'īs al-yahüd Maṣliah ha-Kohen b. Shelomo (1127-39), requesting mediation of a conflict with her late husband's son by a previous marriage and his sister, who had refused to grant her the share of the family apartment that her husband had bequeathed to her. The scribe who wrote the petition adopted the standard mise-en-page of chancery petitions, writing the names of the petitioner and the addressee in the upper left corner. He, too, styled her "the slave" and styled the nagid "your excellency the ga'on" (hadrat ha-ge'onut), and engaged the rhetoric of both ni 'ma and istinā': the slave "wishes that (the nagid) would, in his benefaction (min in 'ämihā), look upon me with a merciful eye"; and he adds, "how fitting it would be for you to confer protection (istin $\bar{a}$ ) on the slave and

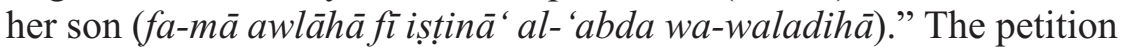
ends, likewise, with phrases taken nearly verbatim from the formulae that closed Fatimid chancery petitions: "to you," in this case the nagid, "belongs the lofty decision in this matter (wa-lahā 'ali al-ra' $\bar{\imath}$

66 'Abd hadrat ha-negidut, takūn misratuhu le-neșah, yunhì ilā sämīhà ("the slave of his excellency the nagid, may his rule be established forever, informs his excellency"). Cambridge University Library, Or. $1081 \mathrm{~J}$ 10, in Hebrew and Judaeo-Arabic, line 3; Mark R. Cohen's edition published on-line by the PGP.

${ }^{67}$ Or. $1081 \mathrm{~J} 10$, lines 9-11. In support of the notion that this line represents mere formulary, cf. the petition of 1151 to the Fatimid vizier Ibn Salār (served under al-Zaăfir, 1149-58), from Jews whose deceased merchant father's property had been impounded, T-S 13 J 20.5, ed. Khan, Arabic Legal and Administrative Documents, doc. 79, verso, margin, lines 1-2: ra'fatan lahum wa-ihsānan 'alayhum. By the Ayyubid period, these terms had become metonyms for the name of the sultan, who in a petition is styled ra'fatuhu wa-ịhsānuhu: T-S H 15.62, ed. ibidem, doc. 89, 370 n. ${ }^{\circ} 1$. 
fi dhälik)." ${ }^{68}$ It is not merely that the genre of the petition and some of its stylistic features had entered the common koine of scribes outside the chancery; the rhetoric of patronage had been frozen and imported to a context outside the court. Isțin $\bar{a}^{c}$, for its part, was now a code-word used in requesting favours of potential patrons. The use of the grammatical superlative awlä, "most fitting," from the same root as wala', patronage, suggests that the phrase was a fossilized remnant of a context in which wala ' and iștina $\bar{a}^{\prime}$ described living and breathing structure of human relationships and had now become ossified as formal rhetoric. That even a scribe from the provincial town of Sunbāt knew the phrase demonstrates the reach of the vocabulary of liberality and its transformation into a broadly used code.

Isțina $\bar{a}^{\prime}$ also assumed shades of the other common words used in lodging appeals, such as khidma. A man in al-Mahalla in the Nile Delta who was being actively pursued by the Ayyubid controller of revenue wrote a desperate letter to an old friend in Fustat asking him to obtain a letter from Shams al-Dīn, the director of revenue, registering him as absent and thus enabling him to avoid paying legitimately; he ended his plea with the phrases: "By all that is due (our) neighborliness and good rearing (together; wa-haqq al-jiwār wa-l-tarbiya), confer this on me (istani ' $n \vec{\imath}$ ) for the sake of God, may He be exalted, and it shall count for you as a treasure (i.e., a reward in the final reckoning; yakūn laka dhakhira)." In this letter, iștinā" appears, like khidma, to denote a service that served both the giver and the receiver. Indeed, the man closes his letter by saying, "I am in God's keep and yours (wa-anā fi hasab allāh wa-hasabika)." 69

${ }^{68}$ Tashtahī min in 'āmihā l-nazar ilayhā bi- 'ayn al-raḥma (lines 7-8); line 18-19. T-S $13 \mathrm{~J}$ 13.6, in Hebrew and Judaeo-Arabic; edited in Cohen, M.R., "Four Judaeo-Arabic Petitions of the Poor from the Cairo Geniza," JSAI, 24 (2000), 459-64; translated to English in idem, Voice of the Poor, doc. 48 (I have departed slightly from his translation); for the details of the case and an earlier petition from the same widow (T-S $10 \mathrm{~J} \mathrm{16.4),}$ see ibidem, doc. 47. The usual closing formula of petitions to Fatimid caliphs is li-mawlanā al-ra'y al- 'ālì (or: 'älì l-ra'y) fì dhālika, with variants attested and different formulae for rulers below the rank of caliph; see Khan, Arabic Legal and Adminsitrative Documents, 314-16. It is thus particularly interesting that the caliphal formula was chosen here, with the exception of the honorific mawläna (the pronoun refers instead to the earlier Hebrew honorific hadra).

${ }^{69}$ Cambridge University Library, Or. $1081 \mathrm{~J}$ 13, in Judaeo-Arabic, right margin. Goitein's edition published on-line by the PGP; see the partial translation in idem, Mediterranean Society, 2, 382 (which omits the closing formulae).

Al-Qanțara (AQ) XXIX 2, julio-diciembre 2008, pp. 341-382 ISSN 0211-3589 
Istina "s eventual reduction to a term tantamount merely to "favour" appears most clearly in a thirteenth-century letter from Abū 1-Majd 'Uzzi'el of Damīra who, having been offered a post as teacher in Minyat Zifta by the muqaddam (judge and local headman) of Minyat Ghamr, Moshe b. Perahya, wrote to inform the latter that he would take up the position only when he was certain that the current teacher had departed from the town and only if the Jewish community sent him an offer in writing. Despite these cold-blooded negotiating tactics, he opens his letter with extravagant thanks for the offer, acknowledging "your kindness (jamīl), benefit (ihsān), and favour (iștinā) for all your servants (khuddām)." 70 Iștinā" appears here as one in a string of terms for kindnesses and favours, an equivalence that suggests that it had lost its specificity as a term of patronage, and that it could not adequately express the sense of "favour" without the help of synonyms.

How clearly do these debased usages of iștina ' reflect earlier ones less debased that bespeak more clearly the affective ties between people? Were it not for their appearance in petitions, I might have said not very clearly. But the link with courtly procedure suggests that, when petitions and, ultimately, letters came to reflect courtly vocabulary in ossified form, the link to the court was tangible rather than merely imitative - even if by now the debased usages were merely utilitarian rhetoric designed to produce results. They could not have been as effective or as widely used if they did not conjure up something; indeed, the prevalence of imitations demonstrates the importance of the original item.

70 T-S 12.360, in Judaeo-Arabic, lines 8-10; he goes on to thank "the Creator for his good health, may God make eternal his benefaction ( $\mathrm{ni}$ ' $\mathrm{ma}$ ) and strengthen the force of his judgments and preserve him for his people": wa-qabbalahu mamlūkuhā qabl al-wuqū 'alayhi wa-i 'tarafa bi-jamīlihā wa-ihsānihā wa-iștinā'ihā li-kull khuddāmihā wa-shukr al-khāliq 'alā 'äfiyatihā allāh yudìm 'alayhi ni 'matahu wa-ayyadahā min sharī'atihi wa-yubqīha li-ummatihi. Goitein's edition published on-line by the PGP. On the judge, the town, and teachers' reluctance to infringe on one another's posts, see idem, Mediterranean Society, 2, 49, 187. 


\section{Patronage and Loyalty}

Remarkably given all this, the range of terms used to describe patronage and loyalty were not mere rhetorical fossils but retained tangible relationships to the social world from which they came.

Nìya

The words for loyalty and other sorts of obligations in these sources are numerous, beginning with sincerity of intention (niy $a$ ) and extending to more binding ties such as pacts and oaths ('uhüd), and ending in the tie of patronage itself (dhimäm). For example, when the ga'on of the Jerusalem yeshiva, Dani'el b. 'Azarya (1051-62), wrote to a Jewish courtier in Fustat and thanked him for a copy of a rescript ( $r u q^{\prime}$ ' $a$, possibly his rescript of investiture as $g a$ 'on) from the chancery of the Fatimid caliph al-Mustansir (1036-94), he wrote: "I understood what you mentioned on the matter of the edict (ruq 'a) which our lord (mawläna - the caliph) delivered to you, may God prolong his days, exalt his fortune, and destroy his foes, his enemies, and those who wish him evil. And I said many pious (sălih) prayers for his Presence (the caliph), since I am obligated to him (mulāzimuhu), night and day, since he has lavished on me his benefactions and favours (hasabamā qad ghamuranī min ihsānihā wa-nawā'ilihā)." ${ }^{71}$ In thanking not just his courtier ally but the caliph himself, the ga'on reveals that he considered his relationship to the caliph as a personal one, and no less the binding for it. As for the courtier who served as intermediary, he describes him as, "after God, may he be praised, a source of this ni ' $m a$, since by your exalted station (jāh) and good intention ( husn al-niya), fortune has come to me before this exalted personage." 72 "Good intention" (husn al-nīya) means something like loyalty; his courtier ally had exchanged two social assets, his high sta-

71 T-S 24.56, in Judaeo-Arabic, verso, lines 3-6; published in Goitein, S.D., "Dani'el b. 'Azarya, nasi ve-ga'on: Berurim u-mismakhim hadashim," (Hebrew), Shalem, 2 (1975-76), 84-89; idem, Palestinian Jewry, 163-68. See also idem, Mediterranean Society, 2, 527, footnote 35; 5, 384 (at footnote 60); 5, 321 (at footnote 46). Also published in Gil, Palestine, doc. 355; see ibidem, secs. 779 and 889. Both identify the author based on handwriting and the recipient based on context.

72 T-S 24.56, verso, lines 7-9. See also verso, line 39, where he further notes the obligation to render thanks for the in 'am of a certain colleague.

Al-Qanțara (AQ) XXIX 2, julio-diciembre 2008, pp. 341-382 ISSN 0211-3589 
tion and his devotion to Dani'el b. 'Azarya, to acquire this benefaction, and the latter did not hesitate to spell out the calculus of benefit.

Intention (niya) appears frequently in similar constructions in the sources, particularly in phrases such as husn al-nīya and ikhläs al-niya, good or sincere intentions. According to the history of 'Abd al-Raḥmān b. al-Jawzī (d. 1200), the Abbasid caliph al-Qā'im (1031-75) swore a pact of loyalty (mithāq, 'ahd) to his Buyid vizier Jalāl al-Dawla in which he promised to "continue in sincerity of intention and friendship (ikhlās al-nīya wa-l-safāa)" toward him, that is, in loyalty. The oath explicitly called on God as witness and, further, invoked the covenant between God and his believers, implying the equivalency between the two pacts and the basis of the human one in the divine one. ${ }^{73}$ Good intention or niy $a$ was a necessary prerequisite to agreeing to any covenant.

\section{'Ahd}

Despite the complications of oaths in Jewish law and their concomitant avoidance of them, Jews were well aware of the importance of niya even in the absence of vows. In the letter I quoted above from Hayya b. Sherira of Baghdad to his protégé Sahlān b. Avraham in Fustat, warning him of the schemes of his political enemies and promising to protect him, Hayya explains that one of his supporters has already informed him "to whom we should write among those who have sincere intentions toward you (munassihika) so that we can thank them, and to whom we should write among your adversaries so that we can make peace between you and them." 74 More than the economy of thanks for loyalty that the ga'on promises Sahlān's supporters, he notes that his loyalists are those whose intentions toward him are sincere. He also describes his obligation toward Sahlān b. Avraham as an 'ahd, a pact or an obligation.

Hayya's use of these idioms of patronage is noteworthy given that he wrote from Baghdad and shared them with the Buyid learned elite.

${ }^{73}$ Ibn al-Jawzī, al-Muntazam fì tārīkh al-mulūk wa-l-umam, Hyderabad, 1357-59; repr. Beirut, 1960, 6-8, 6, 343, quoted in Mottahedeh, Loyalty and Leadership, 56. On niya see further ibidem, 65-67.

74 Mosseri Ia 5 (L 2).

Al-Qanțara (AQ) XXIX 2, julio-diciembre 2008, pp. 341-382 ISSN 0211-3589 
Nor was he the only ga'on of Baghdad to use them. His contemporary Shemu'el b. Hofni (998-1013) was equally conversant in the language of loyalty, as when he wrote to an ally in Fustat in 998 asking him to persuade the wealthy merchants there into sending more frequent letters and, thus, more frequent donations to his yeshiva. He singled out one man for particular praise, a Persian Qaraite named Abū Sulaymān David b. Bapshād, who had rendered some sort of service to the yeshiva, whether in banking or transportation of funds or in outright donations we do not know (Qaraites are attested in all these roles, despite the paradox their assistance to rabbinic institutions appears to suggest). ${ }^{75}$ "Please thank David b. Bapshād on my behalf, may God help him," Shemu'el b. Hofni wrote, "since he has evinced toward me nothing but kindness and benefited me and been loyal to me (innahu awlāni kull jamīl wa-nafa 'anī wa-barranì). Let him know of the esteem (in which I hold) his loyalty (mawqi'a birrihi)." ${ }^{76}$ Birr is yet another amphibolous term, conveying either side of a patronage relationship: it can mean either benefaction or reverence, a polarity I have attempted to render by translating it as loyalty. ${ }^{77}$

The covenantal idiom of 'ahd was used west of Baghdad, too. An otherwise unknown rabbinical teacher in Alexandria named Dani'el b. Ya'aqov wrote to the equally unknown Yiṣhaq ha-Kohen b. Yehuda al-Dimashqi asking him to send greetings to a certain Sa'd al-Mulk - judging by his title, a courtier, bureaucrat, tax-farmer, or other functionary working for the Ayyubids (the letter is undated, but the title is attested in other early Ayyubid letters). ${ }^{78}$ "I ask you to go to the salon in which Suhayl al-Ṣibyān entertains," Dani'el b. Ya'aqov

75 For details on Qaraite alliances with the ge'onim of Baghdad and Jerusalem in the eleventh century, see Rustow, Heresy and the Politics of Community, chapters 5 and 6.

76 T-S 8 J 39.9, in Judaeo-Arabic; published in Goitein, "Letter of the Gaon Samuel b. Hofni, Dated 998, and its Implications for the Biography of the Spanish Poet Isaac b. Khalfon," (Hebrew), Tarbiz, 49 (1979-80), 199-201; and Gil, In the Kingdom of Ishmael, doc. 48 .

77 See also T-S 24.27v, lines 23-37, translated in Goitein, Mediterranean Society, 5, 82; see also ibidem, 528 footnote 165.

78 E.g., Bodl MS Heb. d 66.34, line 20, ed. Goitein, Palestinian Jewry, 319-20; ENA NS 19.31, verso, line 9, Goitein's edition published on-line by the PGP; T-S 13 J 20.6, line 17, Goitein's edition published on-line by the PGP; T-S 12.425, verso, address (El'azar b. Yehudah b. El'azar ha-Kohen, known as Sa'd al-Mulk), Goitein's edition published on-line by the PGP; T-S NS 321.54, line 4, Goitein's edition published on-line by the PGP. For the dating, see idem, Mediterranean Society, 2, 356; 3, 358.

Al-Qanțara (AQ) XXIX 2, julio-diciembre 2008, pp. 341-382 ISSN 0211-3589 
wrote, "and kiss the hand of Sa'd al-Mulk for me. Single him out for my greetings and ask him where the covenant ('ahd) between him and me (has gone; mā hädha al-'ahd allädhì kāna baynī wa-baynahu)." $79 \mathrm{He}$ goes on to explain that he had sent Sa'd al-Mulk numerous letters but heard reply to not a single one of them; his invocation of the covenant of loyalty ('ahd) between them may have been mere hyperbole in view of his eagerness for a reply, but it may also have reflected the history the two men shared and some genuine bond between them.

\section{Dhimām}

The covenantal imagery invoked through the word 'ahd, it seems, applied to men nearly equal in station, while the rhetoric of $i s \underline{t}$ in $\bar{a}^{\text {' }}$ reflected the steep heights of hierarchy that petitions were meant to traverse. But when the obligation incurred between two men reflected a more mildly or temporarily hierarchical arrangement, the term of choice was dhimām. Samhūn b. Dāwūd al-Siqillī, a Jewish merchant from Ifriquiya of the early eleventh century, wrote to the mercantile magnate Yūsuf $b$. "Awkal explaining that he had earned no profit on a shipment of brazilwood that Ibn "Awkal had sent. "I did this," he explained, "because of your patronage (dhimāmika) and because you aid me with your high position $(j \bar{a} h)$ with regard to what I send you at my expense": he was willing to take a loss in doing business on Ibn 'Awkal's behalf because he profited from the arrangement in other ways, acknowledgement that the affective bonds between men could be parlayed into economic and political capital. ${ }^{80}$

79 Wa-as'alaka tamḍi ilā al-qā'a allādhì yaqrī fìhā Suhayl al-Sibyān wa-tuqabbil 'annī yad Sa'd al-Mulk wa-takhușsuhu salāmì wa-taqūl lahu mā hädha l-'ahd allādhì kāna baynī wa-baynahu wa-khattuhu ma 'ì bihi wa-ta'arifuhu katabtu ilayhi 'iddat kutub wa-lam asma ' li-wāhid minhā jawāb. T-S 10 J 13.23, in Judaeo-Arabic, lines 12-17; Goitein's edition published on-line by the PGP. Salon: $q \bar{a}$ ' $a$; $\mathrm{cf}$. idem, Mediterranean Society, 4, 69-70 (the translation of "schoolhouse" suggested there does not fit the context).

${ }^{80} \mathrm{Fa}$ 'altu dhālik li-dhimāmika 'indī wa-mā tu' 'ayyinunì bihi bi-jāhika fì mā ba'athtu bihi ilayka li-khāsșatī, Budapest, Hungarian Academy of Sciences, Kaufmann Collection, 13, line 6; published by Goitein, "The Jewish Trade in the Mediterranean at the Beginning of the 11th Century, from the Archives of Ibn 'Awkal Family," (Hebrew), Tarbiz, 37 (1968), 64-66 (footnote 16); Goitein's corrected edition published on-line by the PGP. See also further comments on this letter as a reflection of informal cooperation 


\section{In Praise of Form}

The similarities and differences between court-sponsored and documentary sources in their uses of the idioms of patronage suggest several conclusions.

First, the comparison sheds light on the relationship between Jews and the empire that ruled them, in terms of both substance and style. Crone contends that the Abbasids failed to convince anyone outside the immediate confines of Baghdad of the dynasty's ideological programme. ${ }^{81}$ My material suggests otherwise: Jews engaged willingly and sincerely in the discourse of patronage that received its characteristic shape at the Abbasid court. Jewish leaders embraced imperial rule since it offered them, too, a means of self-legitimation.

This is by no means to suggest, in simplistic fashion, that the Jews merely imitated what the few of them learned who were fortunate enough to gain appointments at court. Jews can be said to have imitated courtly manners no more than they can be said to have imitated the Arabic speech and literature that was their native and, in most cases, only means of communication. On the contrary: the idioms were theirs, and the degree to which they used the vocabulary of patronage and loyalty reflects the degree to which it pervaded the entire society, or at least that urban and seaborne part of it reflected in the Geniza. This included not merely those literate enough to write, but those with enough access to the literate few that they could have documents written for them. Idioms of patronage allowed Jews to conduct business and politics, and, as suggested by the letters of the ge'onim who headed the rabbinic academies to which most Jews offered their allegiance, had a hand in enabling rabbinic Judaism to become and remain the hegemonic form of the religion throughout the Middle Ages. That is to say: only to the extent that Jewish leaders adopted the forms and styles of the political relationships I have discussed above could they hope to amass and retain followers.

Like writing itself, then, idioms of patronage constituted a linguistic technology whose effect was to render its users powerful, and to

(mu'ämala) and reciprocity of service among traders in Stillman, N.A., "The Eleventh Century Merchant House of Ibn 'Awkal (A Geniza Study)," Journal of the Economic and Social History of the Orient, 16 (1973), 23.

81 Crone, Slaves on Horses, 73.

Al-Qanțara (AQ) XXIX 2, julio-diciembre 2008, pp. 341-382 ISSN 0211-3589 
produce binding ties. This suggests that the effects of imperial rule on religious minorities, though pervasive, could have unexpected consequences, even if those consequences varied considerably depending on one's analytical framework: in this case, empire itself allowed the Jewish diaspora to spread in unprecedented fashion and, despite such wide geographic dispersion, to experience a sense of unity - one centered, in part, on Baghdad or the idea of it. Why this was especially true after the political decline of the Abbasid capital in the tenth century - why the apotheosis of the geonim of Baghdad in Jewish literature postdated the decline of Baghdad in political and economic reality -is a question for another study.

Second, the comparisons I have drawn above between courtly and non-courtly uses of the idioms of patronage suggest that one might fruitfully reconsider the respective roles of formalism and informalism in the medieval Near East. Patronage, which began as a formal legal and political institution, softened and spread to become the loose form of patronage reflected in the Geniza sources; meanwhile some of the language used to express ties of patronage, such as iștinā', began informally enough among Abbasid and Buwayhid functionaries but hardened to become formal rhetoric invoked in the most stereotyped way.

The combination of linguistic formalism with political informalism is a particularly intriguing one, because it suggests something about the way language drives human relationships. The point is perhaps most fruitfully made by comparing medieval political relationships with modern ones. Industrialized societies with bureaucratic states tend to lead to relations among groups that are formal, corporative, legalized, and bureaucratized, and to relations between individuals that are informal and understood as the product of choice and affect. Medieval politics, by contrast, rested on formal ties between individuals while tending to repel fixed and formal bonds among groups.

An analogous point can be made about the use of formulae in written documentation; it was, in fact, made brilliantly if abstrusely by John Wansbrough. ${ }^{82}$ When one considers chancery practice, letter writing, and the composition of legal documents, that is, diplomatic, broadly across the Mediterranean basin, it seems that precisely the el-

82 Wansbrough, J.E., Lingua Franca in the Mediterranean, Richmond, Surrey, 1996.

Al-Qanțara (AQ) XXIX 2, julio-diciembre 2008, pp. 341-382 ISSN 0211-3589 
ements of language that we might consider obligatory, such as choice of language, choice alphabet as a function of language, and the use of particular phrases, were in fact the most flexible in practice. Jews wrote Arabic mainly in Hebrew characters; but on occasion they wrote Hebrew, and on still other occasions, Hebrew in Arabic characters and Arabic in Arabic characters. Likewise, scribes and diplomats used what worked to render the documents they wrote legally and politically binding, and the documents they wrote suggest that choice of language and alphabet were less important than conveying a particular kind of phrase that might have the desired effect. The large number of calques and outright stylistic thefts one finds in legal documents attest that scribes were hardly above domesticating an entirely foreign tradition if this won them the results they sought: legal enforceability. At the same time, precisely those features of documents that we might imagine to have varied across legal and cultural traditions - form (which we see as being standard within a particular cultural setting) and instrumental force (which we see as a mere accident of local enforcement) - appear with remarkable consistency across vastly different legal, political, and literary traditions.

I can hardly do Wansbrough's thesis justice in the limited space at my disposal, but I mention it here to call attention to the broader conclusions one might draw from the remarkable consistency with which the relationships I have discussed recur in vastly differing written material, and with which the specific idioms that one might imagine flourished only in particular contexts in fact surpassed the boundaries of the court and served political functions in other contexts in which men and women, for varying purposes, chose to cultivate relationships across social hierarchies.

Recibido: $15 / 04 / 08$

Aceptado: 05/06/08 